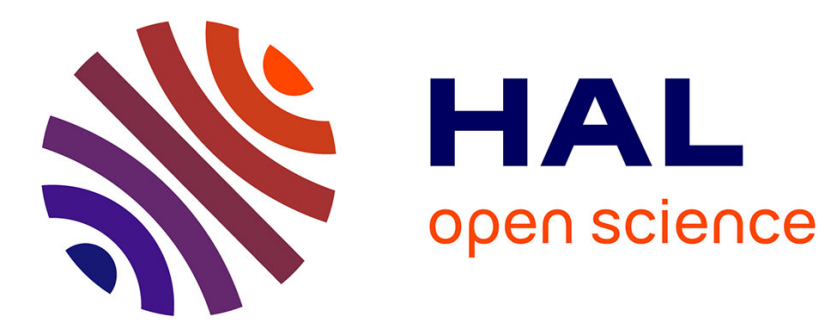

\title{
Bank Regulatory Capital Adjustment and Ultimate Ownership Structure: Evidence from European Commercial Banks
}

\author{
Laetitia Lepetit, Amine Tarazi, Nadia Zedek
}

\section{To cite this version:}

Laetitia Lepetit, Amine Tarazi, Nadia Zedek. Bank Regulatory Capital Adjustment and Ultimate Ownership Structure: Evidence from European Commercial Banks. 2012. hal-00918577

\section{HAL Id: hal-00918577 \\ https://hal-unilim.archives-ouvertes.fr/hal-00918577}

Preprint submitted on 13 Dec 2013

HAL is a multi-disciplinary open access archive for the deposit and dissemination of scientific research documents, whether they are published or not. The documents may come from teaching and research institutions in France or abroad, or from public or private research centers.
L'archive ouverte pluridisciplinaire HAL, est destinée au dépôt et à la diffusion de documents scientifiques de niveau recherche, publiés ou non, émanant des établissements d'enseignement et de recherche français ou étrangers, des laboratoires publics ou privés. 


\title{
Bank Regulatory Capital Adjustment and Ultimate Ownership Structure: Evidence from European Commercial Banks
}

\author{
Laetitia Lepetit, Amine Tarazi, Nadia Zedek* \\ Université de Limoges, LAPE, 5 rue Félix Eboué, 87031 Limoges Cedex, France
}

Preliminary draft: May 24, 2012

Please do not quote without the permission of the authors

\begin{abstract}
We empirically investigate whether a bank's decision to recapitalize is influenced by its ownership characteristics, particularly the separation between voting and cash-flow rights of the bank's ultimate owner. We use a novel hand-collected dataset on bank ultimate control and ownership structure of 442 European commercial banks to estimate an ownershipaugmented capital adjustment model. We find that when the ultimate owner's voting and cash-flow rights are identical, banks actively (as opposed to passively shifting earnings to capital stock) and equally adjust their capital upwards (i.e. raise equity) and downwards (i.e. repurchase equity) to reach their target level. However, a gap between voting and cash-flow rights of the ultimate owner makes banks reluctant to actively adjust their capital position upwards, presumably because they fear control dilution. Further investigation shows that such a behavior is more pronounced if the ultimate owner is a family or a state, or if the bank is headquartered in a country with weak shareholder protection. Our findings have several policy implications on the road to the final stage of Basel III in 2019.

JEL Classification: G21, G28, G32
\end{abstract}

Keywords: Ownership structure, pyramids, regulatory bank capital, European banking, adjustment speed, voting rights, cash-flow rights

*Corresponding author. Tel: + 33555149251

E-mail addresses: laetitia.lepetit@unilim.fr (L. Lepetit), amine.tarazi@unilim.fr (A. Tarazi), nadia.zedek@unilim.fr (N. Zedek) 


\section{Introduction}

Bank capital plays a central role in bank regulation. The global financial crisis triggered in 2007 has led the Basel Committee on Banking Supervision (BIS, 2010a) to strengthen the existing capital requirements and to improve the quality of regulatory capital. The definition of Tier 1 regulatory capital has been narrowed by excluding preference shares that were included in the previous (Basel II) definition of Tier 1 capital. To comply with these new regulatory capital requirements, banks need to raise their equity capital or reduce their scale. Although banks usually hold regulatory capital buffers (i.e. above the minimum requirements) these changes raise an important question: how do banks adjust their capital depending on their control and ownership structure? We specifically question how control and ownership structure, namely the gap between voting and cash-flow rights of the ultimate owner, affect the bank's decision to adjust toward target capital.

It is well known that banks are often reluctant to raise equity capital. The arguments provided by the existing theoretical and empirical literature regarding the reluctance of banks to recapitalize focus on the costs related to raising equity. According to the pecking-order theory, issuing new equity in the context of asymmetric information signals bad news to the market (Myers \& Majluf, 1984). This may lead to share price reductions affecting the bank's economic value negatively. Accordingly, banks rely more on internal funds and raise equity in last resort. Altinkihc and Hansen (2000) also report higher transaction costs for equity issuance $(5.38 \%$ of the issue proceeds versus $1.09 \%$ for debt). Furthermore, increasing equity requires a time delay which impedes immediate recapitalization (Peura \& Keppo, 2006). During this delay, banks might breach the minimum capital requirements. Hence, banks face high costs due to increased regulatory intervention and surveillance (Peek \& Rosengren, 1997), as well as liquidation and financial distress costs including the loss of charter value (Keeley, 1990). Because of these adjustment costs, banks hold capital buffers and are likely to adjust their capital ratios by modifying the size of their balance sheet. The empirical literature on how banks manage their capital ratios provides ambiguous results. Ivashina \& Scharfstein (2010) show that banks preferred to cut their risky assets (new lending) instead of issuing new equity during the 2008 financial crisis. Laderman (1994) finds that undercapitalized bank holding companies decrease asset growth rather than issue new common stock, because issuing new equity reduces shareholders' wealth. Jacques and Nigro (1997) find that severely undercapitalized banks increase their capital ratios by mainly reducing portfolio asset risk 
because they face higher recapitalization costs. Conversely, Rime (2001) finds that Swiss banks adjusted their regulatory risk-based capital ratios by increasing capital rather than reducing asset risk due to the absence of a developed market for asset-backed securities in Switzerland.

While there is a very large strand of literature that investigates why banks avoid recapitalization, research on the driving forces behind banks' decision to recapitalize is relatively scarce. Managers/controlling shareholders may adapt their financing policies to inflate their voting power and avoid the dilution of their control rights ((Stulz, 1988), (Harris \& Raviv, 1988)). Other studies investigate how firms choose between different equity issue methods (for instance rights offerings and private placements). They find that familycontrolled firms favor rights offerings to avoid control threats (Cronqvist \& Nilsson, 2005). Focusing on banking firms, Hyun and Rhee (2011) theoretically show that if a bank's decision to recapitalize is made by existing powerful shareholders, it will satisfy the higher capital ratio by reducing risky assets (especially loans) rather than by issuing new shares. Banks are therefore likely to reduce loans in order to avoid ownership dilution of the existing shareholders.

In our study, we build on the law and finance theory (La Porta et al., 1998) and empirically test whether ownership characteristics affect the banks' decision to recapitalize. More precisely, we focus on the separation between voting and cash-flow rights of the ultimate owner and examine whether banks controlled by a shareholder with and without deviation between both rights behave differently in adjusting their capital ratios. The performance of banks depends on the extent of the deviation between voting and cash-flow rights (Azofra \& Santamaria, 2011) and therefore banks' capital ratios might fluctuate and adjust to their optimal levels differently. A controlling shareholder without deviation between both rights is more oriented toward profit maximization and consequently has stronger incentives to force the bank to adjust its capital ratio and maintain it at its optimal level, regardless of the potential control and ownership dilution costs that may arise from recapitalization. Conversely, a controlling shareholder with deviation between both rights is more oriented to reap private benefits of control ((Bebchuk et al., 2000), (Claessens et al., 2002)). Hence, we conjecture that a controlling shareholder with deviation between both rights is more averse to control dilution leading her/him to curb recapitalization that could dilute her/his controlling position by allowing a new shareholder's entry that may contest her/his current voting power. 
We contribute to the existing literature in several directions. First, we compile new data on ultimate control and ownership structure of 442 commercial banks across 17 European countries. Unlike previous studies ((Caprio et al., 2007), (Laeven \& Levine, 2009)), we include both publicly listed and privately owned banks. We then compute the ultimate owner's voting and cash-flow rights following La Porta et al. (1999) and disentangle between shareholders with and without separation between both rights. Second, we examine whether such a separation affects a bank's decision to recapitalize, a question which to our knowledge has not been addressed before. For this purpose, we adapt a capital adjustment model used in the literature and test for potential asymmetries in the adjustment speed toward long term capital targets. Such asymmetries could possibly be the outcome of differences in control/ownership dilution costs depending on the presence or absence of a gap between ultimate owners' voting and cash-flow rights. Hence, we contribute to the literature ${ }^{1}$ investigating differences in adjustment speeds by considering the impact of control/ownership dilution costs beyond the well documented costs (transaction, asymmetric information and regulatory costs). Third, by focusing on Europe we are able to draw policy implications for bank regulators. Deviation between voting and cash-flow rights is more acute in Europe compared to other countries (for instance the U.S.) with more diffused ownership (La Porta et al., 1998). We hence carry out a study on European regulatory bank capital and provide another driving factor behind the reluctance of banks to raise equity: ownership structure. Finally, we contribute to the recent regulatory debate regarding the limitation of Tier 1 regulatory capital to ordinary shares and draw potential implications.

Our key findings are as follows. On the one hand, banks controlled by a shareholder without separation between voting and cash-flow rights equally adjust their capital upwards and downwards and do not appear to fear control dilution. On the other hand, banks controlled through a gap between both rights adjust their capital downwards identically to banks without such a gap but are reluctant to actively adjust their capital position upwards. This finding suggests that banks controlled through separation between both rights fear control dilution and consequently curb recapitalization. Furthermore, we find that the fear of control dilution is more pronounced if the shareholder is a family or a state or when the bank is established in a country with weak shareholder protection.

The remainder of the paper proceeds as follows. In section 2, we present our research hypotheses. Section 3 describes the data, defines ownership variables and provides some

\footnotetext{
${ }^{1}$ See (Flannery \& Rangan, 2006), (Berger et al., 2008), (Jokipii \& Milne, 2011), (Memmel \& Raupach, 2010) and (Byoun, 2008).
} 
descriptive statistics. In section 4, we specify the model used to test our hypotheses. Section 5 provides estimation results. In section 6, we carry out some extensions and perform robustness checks. Section 7 concludes.

\section{Research hypotheses}

In this paper, we build on two strands of the literature: the bank capital ratio adjustment literature and the corporate governance and ownership structure literature.

Banks face a trade-off when they choose the appropriate level of their capital ratios. On the one hand, banks have to hold a minimum level to comply with regulatory requirements and to satisfy market participants (market discipline). On the other hand, banks are also expected to maximize the return to shareholders. This leads them to a target capital ratio. Previous studies find evidence of such a target and argue that bank capital ratios do not fluctuate randomly ((Memmel \& Raupach, 2010), (Berger et al., 2008), (Flannery \& Rangan, 2008)). However, positive (negative) random shocks may affect bank capital ratios leading to positive (negative) deviations of the capital ratio from the target level. Consequently, bank management is expected to periodically adjust the capital ratio. When a positive exogenous shock leads to a positive deviation of the current capital ratio from its target value, bank insiders will decrease the current capital ratio to adjust to the target. This can be achieved via a combination of equity repurchase, an increase in dividend payment, or an upward adjustment in asset size (or in risk-weighted assets). In the event of a negative shock the bank will need to issue new equity, decrease its dividend payment, or decrease its asset size (or risk-weighted assets). For the controlling shareholder recapitalization (equity issues) may dilute both the control and cash-flow (dividend) rights whereas equity repurchase may reinforce both rights. We therefore expect that the behavior of banks in terms of capital adjustment will be influenced by their control/ownership characteristics. Hence, beyond the costs highlighted in the literature (transaction, asymmetric information and regulatory costs), we conjecture that banks will also consider potential control and/or ownership dilution costs against operating with a suboptimal capital ratio (below or above the target capital ratio). Using the law and finance theory (La Porta et al., 1998), we consider in our analysis two kinds of shareholders that may potentially behave differently when capital levels move above or below their target level. Many studies focus on the separation between voting and cash- 
flow rights of the controlling shareholder ${ }^{2}$. A shareholder may control/hold a company without any discrepancy between voting (i.e. the right to control) and cash-flow (i.e. the right to earn dividends) rights. However, pyramidal ownership structures, dual class shares and cross-holding mechanisms allow large shareholders to exercise effective control over a company with a relatively small stake of cash-flow rights (Bebchuk et al., 2000), i.e. control the company with a large gap between voting and cash-flow rights.

Previous studies argue that firms controlled by a shareholder without separation between voting and cash-flow rights exhibit higher performance ((Azofra \& Santamaria, 2011), (Claessens et al., 2002)). Thus, a shareholder without separation between both rights has stronger incentives to achieve better performance and is more likely to timely adjust the bank's capital closely to its optimal level. Such a shareholder is expected to adjust the capital ratio in both directions: upwards (i.e. equity issues) and downwards (equity repurchases). In addition, such a shareholder may have lower incentives to curb recapitalization through new equity issue because the positive effect of recapitalization (moving to the target capital ratio) might outweigh its potential negative effect (loss in dividends).

Hypothesis 1.a (H1.a): Banks controlled by a shareholder with equal voting and cash-flow rights adjust their capital regardless of their initial position; i.e. above (equity repurchase) or below (equity issue) the target capital ratio.

Hypothesis 1.b (H1.b): When there is no difference between the ultimate owner's voting and cash-flow rights, upward and downward equity adjustments are identical. Such a shareholder equally weighs equity issues and repurchases.

A broad literature argues that deviation between voting and cash-flow rights leads to poorer performance. This is due to the ability of the controlling shareholder to expropriate minority shareholders without bearing the financial costs of expropriation ${ }^{3}$ ((Azofra \& Santamaria, 2011), (Claessens et al., 2002)). Thus, a controlling shareholder with separation between both rights is less oriented toward profit achievement and is consequently expected to have lower incentives to adjust the bank's capital ratios and operate with a target. Furthermore, such a shareholder will differently weigh equity issues and repurchases. It could be argued that, to raise equity capital, such a shareholder could provide the required equity

\footnotetext{
${ }^{2}$ See (La Porta et al., 1999), (Claessens et al., 2000), (Claessens et al., 2002), (Faccio \& Lang, 2002), (Almeida \& Wolfenzon, 2006), (Boubakri \& Ghouma, 2010), (Almeida et al., 2011), (Anon., n.d.), (Azofra \& Santamaria, 2011)...

${ }^{3}$ Many studies argue that expropriation is costly (Maury \& Pajuste, 2005), (La Porta et al., 2002), (Burkart et al., 1998).
} 
itself or take it from any entity she/he controls in the pyramid (Almeida \& Wolfenzon, 2006). However, this may increase the proportion of cash-flow rights held in the bank leading to high expropriation costs ((La Porta et al., 2002), (Maury \& Pajuste, 2005)). Furthermore, entities located at the bottom of the pyramid, i.e. with deviation between control and ownership, are generally less profitable (Almeida et al., 2011). This may reduce the controlling shareholder's incentives to increase-by providing new equity- her/his cash-flow rights in such entities. The other option to recapitalize is to issue new equity to outsiders. However, this may dilute both the control and dividend rights of the controlling shareholder if she/he has lower cash-flow rights than voting rights. Assuming that recapitalization is made by issuing common shares that provide one share one vote, ownership dilution is less constraining for such a shareholder since her/his ownership share is in general very small. For example, in the case of Spain, Azofra and Santamaria (2011) find that whenever there is a gap between voting and cash-flow rights of the controlling shareholder, her/his cash-flow rights reach on average only $17 \%$ while the voting rights rise to $81 \%$. In contrast, the dilution of voting rights is more troublesome. The entry of a new shareholder with a considerable voting power could contest the current controlling shareholder. The literature distinguishes two potential situations. First, if the new shareholder colludes ${ }^{4}$ with the current controlling shareholder to expropriate minority shareholders ((Shleifer \& Wolfenzon 2002), (Laeven \& Levine, 2008)), the latter would have to share with the former the diverted resources that she/he would have solely pocketed in the absence of the new shareholder. Second, if the new shareholder monitors the current controlling shareholder ((Maury \& Pajuste 2005), (Pagano \& Röell, 1998), (Bennedsen \& Wolfenzon, 2000), (Gomes \& Novaes, 2001)), the latter would not be able to divert resources as easily as before. In any case, the current shareholder has something to lose and her/his loss will not be offset by the positive outcomes of recapitalization (moving to the target level) as her/his cash-flow rights are very limited in the bank. If such banks feel the need to adjust their capital ratios because of extra pressure from regulators or from the market, it might be optimal for them to increase their capital ratios by selling assets instead of raising equity.

Hypothesis 2 (H2): Banks with and without divergence between voting and cash-flow rights behave identically when they face a surplus in capital: the downward adjustment speed toward the target is the same for both types of banks.

\footnotetext{
4 The literature on complex ownership structures argues that coalitions may increase the efficiency of expropriation by reducing expropriation cost (Maury \& Pajuste, 2005). However, the resulting benefit from increased expropriation efficiency might not always compensate the loss in the diverted share for the current controlling shareholder.
} 
Hypothesis 3 (H3): When there is divergence between voting and cash-flow rights, the adjustment speed toward the target capital is asymmetric: slow if the bank needs to raise equity and fast if it has to decrease equity.

\section{Data, Ultimate Ownership Variables and Descriptive Statistics}

\subsection{Sample}

Our sample covers 442 commercial banks across 17 Western European countries ${ }^{5}$. Data on bank balance sheets and income statements come from Bankscope while data on bank ultimate ownership and control are collected from several sources: Bankscope, Amadeus and annual reports. We also use the World Bank database to collect our macroeconomic indicators. We identify in Bankscope 1533 commercial banks for which income statements and balance sheets are provided for the 2002-2010 period. We use consolidated data but also refer to unconsolidated statements when consolidated data are not available. Among these 1533 commercial banks, information on risk-based Tier 1 capital ratio was missing for 1047 banks. This leaves us with 486 commercial banks. We further delete 8 banks for which the Tier 1 risk-based capital ratio is greater than $40 \%$. We also omit 8 other banks involved in mergers and acquisitions ${ }^{6}$. Hence, we end up with a sample of 470 commercial banks. We then move to construct the control chains of these banks.

\subsection{Building of Control Chains}

Based on this sample of 470 banks, we gather data on bank ultimate control/ownership. We start by collecting information on direct ownership from Bankscope. For incomplete information or information not available in Bankscope, we search in annual reports. We classify a bank as a controlled bank if it has at least one shareholder with direct voting rights that sum up to $10 \%$ or more ${ }^{7}$. This control level is used because it provides a significant threshold of votes and most of our sample countries mandate disclosure of at least $5 \%$ of ownership $^{8}$. In addition, this control level is more accurate in the case of banks due to greater

\footnotetext{
5 These countries are: Austria, Belgium, Denmark, Finland, France, Germany, Greece, Ireland, Italy, Luxembourg, Netherlands, Norway, Portugal, Spain, Sweden, Switzerland and United Kingdom.

${ }^{6}$ We identify all banks for which total asset growth rate is greater than $35 \%$. Then we check in Bankscope if such a bank experienced a merger-acquisition event. This applies to 8 banks.

${ }^{7}$ As a robustness check, we carry out the same analysis by considering $20 \%$ as a control threshold.

${ }^{8}$ For example in France, Germany and Spain, owners that hold more than 5\% must disclose their identity. The disclosure threshold is $2 \%$ in Italy and $3 \%$ in the United Kingdom.
} 
diffusion of ownership compared to non-financial firms ((Prowse 1995), (Faccio \& Lang, 2002)). Out of 470 commercial banks, we have 40 banks that are widely-held (i.e. no shareholder controls $10 \%$ or more) and 430 are controlled banks. To build the control chains, we focus on these 430 controlled banks. If the controlling shareholder is independent, i.e. she/he is not controlled by another shareholder, we consider her/him as the ultimate owner of the votes. If, however, the controlling shareholders identified at this stage are themselves corporations, we continue the process and identify large shareholders (control 10\% or more) in these corporations until we find the ultimate owners of the votes. We are not able to complete the full process for 28 banks because of lack of data. Hence, we end up with a final sample of 442 commercial banks. Most of our data on ownership structure are for 2007 and 2008. We occasionally use observations from 2005, 2006, 2009 and $2010^{9}$. Previous studies argue that ownership patterns are relatively stable over time ((La Porta et al., 1999), (Caprio et al., 2007), (Laeven \& Levine, 2008)). We therefore do not view this as a serious shortcoming to perform our analysis where the focus is on a dummy variable that captures the presence or absence of a gap between control and ownership (control-ownership wedge). Once we get our control chains, we classify the ultimate owners of the controlled banks into four main categories: BANK if the ultimate owner is a widely-held bank, FAMILY if the ultimate owner is an individual or a family, STATE if the ultimate owner is a state or a public authority, and finally the category OTHER which includes the other types of ultimate owners (Industrial firm, financial and insurance companies, Mutual and Pension funds, Foundations and Research institutes, Managers and finally Cross-holdings) ${ }^{10}$.

Table 1 presents the distribution of European commercial banks by country as well as the representativeness of our final sample. To assess the representativeness of our sample, we compare the aggregate total assets of sample banks in a given country to the aggregate assets of all the banks covered by Bankscope in the same country. On average our final sample accounts for more than $50 \%$ of total bank assets in every country except for Austria (43\%).Table 2 presents some general descriptive statistics for both the full sample available in Bankscope and our final sample. It shows no major differences between the two samples.

\section{[Insert Tables 1 and 2 about here]}

\footnotetext{
${ }^{9}$ Observations on ownership are respectively 48\%, 29\%, 11\%, 6\%, 4\% and 2\% for 2007, 2008, 2009, 2010, 2006 and 2005.

${ }^{10}$ We consider the classification provided in Bankscope.
} 


\subsection{Measuring Ultimate Ownership}

To investigate the potential asymmetries in the dynamics of bank capital depending on the presence or the absence of control-ownership deviation, we compute the voting and the cashflow rights of the ultimate owner. For this purpose, we use the last link principle method initially proposed by (La Porta et al., 1999). This method is described below.

\section{Voting Rights (VR) and Cash-Flow Rights (CFR)}

The controlling shareholder can control (hold) a bank directly and/or indirectly. The voting rights (cash-flow rights) of the controlling shareholder are the sum of direct and indirect control (ownership) in the bank. Direct control (ownership) involves shares registered in the controlling shareholder's name. Indirect voting rights (cash-flow rights) involve bank shares held by entities that the ultimate owner controls.

For example, assume that $U O$ is the ultimate owner of bank $B$ and the control chain from $U O$ to $B$ is a sequence of two other corporations $C 1$ and $C 2$ (each entity in the control chain holds 10 per cent or more of voting rights over the next one). Assume $U O$ holds $10 \%$ in $C 2, C 2$ holds $20 \%$ in $C l$ which in turn holds $30 \%$ in the bank $(B)$, i.e. the control chain is presented as follows $U O \rightarrow(10 \%) C 2 \rightarrow(20 \%) C 1 \rightarrow(30 \%) B$, indirect voting rights of $U O$ computed on the basis of the last link principle method are equal to $30 \%$ whereas the cash-flow rights are equal to $0.6 \%$, i.e. $10 \% * 20 \% * 30 \%$. If the ultimate owner controls bank B through multiple chains, we sum the voting rights (cash-flow rights) across all of these chains. Suppose that UO controls (holds) directly an additional proportion of $40 \%$ in bank $\mathrm{B}$, the voting rights of UO are equal to $70 \%$, i.e. VR $=30 \%+40 \%$ whereas the cash flow-rights are $40.6 \%$, i.e. CFR $=0.6 \%+40 \%$. If the bank is widely-held or in the case of cross holdings we set its voting rights (cash-flow rights) equal to zero. When multiple shareholders have $10 \%$ or more of the votes in the bank, we define the controlling shareholder as the owner with the greatest voting rights.

\section{Divergence between Voting and Cash-Flow Rights (WEDGE)}

Substantial discrepancies between voting and cash-flow rights may exist in the presence of indirect control chains. In our analysis we define the control-ownership deviation as the difference between the voting and the cash-flow rights (WEDGE) (La Porta et al., 1999). We 
note $\mathrm{W}$ the dummy variable equal to one if WEDGE is not null, and zero otherwise. In the previous example, WEDGE is equal to $29.4 \%$, i.e. $70 \%-40.6 \%$.

Appendix A reports some examples on the control chains and the calculation of the voting and the cash-flow rights using a $10 \%$ control threshold as well as a $20 \%$ control level.

\subsection{Ultimate Ownership in Western Europe and Descriptive Statistics}

Panel A of Table 3 reports the composition of our sample according to ownership structure using a control threshold of $10 \%$. Our data show that $89 \%$ of European commercial banks are controlled by at least one shareholder whereas widely-held banks account only for $11 \%$. This sample composition allows us to easily test our hypotheses. The data also suggest that the nature of controlling shareholders is diverse. On average, widely-held banks (BANK) control $38 \%$ of the banks in our sample. Further, individuals/families (FAMILY) and government (STATE) are important owners in our sample of European banks. They control $21 \%$ and $14 \%$ of banks respectively. When we divide our sample in two subsamples depending on the presence or the absence of the separation between VR and CFR, we observe that more than $44 \%$ of the controlled banks have an owner with control-ownership deviation. Besides, we notice that FAMILY ownership and STATE ownership prevail in the subsample where the ultimate owner exerts control through control-ownership gap. They respectively control $27 \%$ and $24 \%$ of the banks with control-ownership divergence against $17 \%$ and $7 \%$ of the banks without such divergence. This finding is consistent with the view that divergence between control and ownership could enable ultimate owners and especially families to expropriate minority shareholders and divert a large fraction of resources (Almeida \& Wolfenzon, 2006). In contrast, widely-held banks (BANK) control 53\% of the banks without control-ownership deviation and only $19 \%$ of the banks with such a deviation. This is consistent with the view that widely-held banks are less likely to engage in expropriation as the resulting benefits are distributed among multiple owners and because regulation makes expropriation more costly (Haw et al., 2010).

\section{[Insert Table 3 about here]}

On the whole, the descriptive statistics reported in Table 4 show that banks controlled through different rights hold lower Tier 1 risk-based capital ratios, are less profitable and rely more on credit activities. Furthermore, the proportion of banks with equal rights that pay dividends is higher than that of banks with different rights. The latter might pay lower 
dividends to more easily adjust their capital ratios via internal funds, or because of the effect of expropriation (Faccio et al., 2001). Finally, our data show that on average, the ultimate owner holds almost $57 \%$ of equity capital (equivalent to $70 \%$ if we focus only on controlledbanks) when the gap between both rights is zero. This high percentage (70\%) is consistent with the presumption that a controlling shareholder with equal rights is more inclined toward profit maximization (Azofra \& Santamaria, 2011). In contrast, a controlling shareholder with different rights holds on average around 19\% (CFR) and controls 84\% (VR). On average, the wedge between VR and CFR is $65 \%$. These figures suggest that when there is a gap between both rights, the controlling shareholder is more inclined to protect her/his voting rights rather than her/his cash-flow rights as the latter are almost three times lower than the former.

We now move to the approach we follow to investigate the impact of ownership structure and divergence between VR and CFR on banks' capital adjustments.

\section{[Insert Table 4 about here]}

\section{Methodology}

In this paper we aim to investigate how banks adjust their Tier 1 capital ratio depending on their control/ownership pattern. Banks have two main channels to adjust their capital ratios: the liability side, i.e. changes in capital and the asset side, i.e. adjustments in asset size or risk-weighted assets. To test our hypotheses, we adapt a capital adjustment model commonly used in the literature to focus only on adjustments through the liability side (changes in capital). We also introduce flexibility to allow for asymmetric upward and downward capital adjustment rates depending on the presence or absence of a gap between voting and cash-flow rights of banks' ultimate owners. Asymmetries in capital adjustment rates possibly reflect differences in the cost of control dilution stemming from recapitalization. Hence, if a bank adjusts its capital at the same rate when it faces an upward or downward change, we would presume that such a bank does not fear control/ownership dilution. If a bank adjusts its capital at a lower rate when it needs to increase capital (upwards) than when it has to reduce it (downwards) we conjecture such a behavior is driven by the fear of control/ownership dilution and that the bank will most likely move to the target by adjusting the asset side of the balance sheet (by selling assets or reshuffling its asset portfolio by substituting safe assets to risky assets). 


\subsection{Baseline Capital Adjustment Model}

Based on previous studies ((Berger et al., 2008), (Byoun, 2008), (Flannery \& Rangan, 2006)), we consider the following capital partial adjustment model:

$$
\mathrm{K}_{\mathrm{it}}-\widetilde{\mathrm{K}}_{\mathrm{it}-1}=\lambda\left[\left(\frac{\mathrm{K}_{\mathrm{it}}}{\mathrm{A}_{\mathrm{it}}}\right)^{*} \mathrm{~A}_{\mathrm{it}}-\widetilde{\mathrm{K}}_{\mathrm{it}-1}\right]
$$

Where $K_{i t}$ refers to the book value of capital for bank $i$ at time $t$, measured as Tier 1 regulatory capital (T1). $A_{i t}$ is either bank total assets (TA) or risk-weighted assets (RWA). $\left(\frac{K_{i t}}{A_{i t}}\right)^{*}$ is the target (desired) Tier 1 simple (non risk-based) or risk-based capital ratio for bank $i$ at time $t$, depending on the definition of $A_{i t}$ we consider. $\widetilde{K}_{i t-1}$ is the adjustment model's starting point. The right-hand side of equation (1) corresponds to the required change in bank capital to adjust to the target whereas the left-hand side is the observed change in bank capital, i.e. the amount of bank capital devoted to adjust to the target between $\mathrm{t}-1$ and $\mathrm{t}$. Hence, in this specification, the coefficient $\lambda$ represents the capital adjustment speed, i.e. the proportion a bank adjusts via capital changes to move to the target level.

The observed change in bank capital in equation (1) can arise from passive management, i.e. shifting earnings to the stock of capital in the preceding period or active management, i.e. a change in dividend policy and equity issues/repurchases. To distinguish between these two alternatives, we consider two different definitions for $\widetilde{\mathrm{K}}_{\mathrm{it}-1}$. First, $\widetilde{\mathrm{K}}_{\mathrm{it}-1}$ is defined as $\mathrm{K}_{\mathrm{it}-1}$, i.e. the lagged value of $K_{i t}$. In this case, the left-hand side of equation (1) is the sum of both passive and active changes in bank capital (i.e. the whole change). The second definition for $\widetilde{\mathrm{K}}_{\mathrm{it}-1}$ allows us to isolate the active change in bank capital, i.e. equity issues/repurchases ${ }^{11}$. $\widetilde{\mathrm{K}}_{\mathrm{it}-1}$ is therefore computed as the sum of the lagged value of Tier 1 regulatory capital $\left(\mathrm{K}_{\mathrm{it}-1}\right)$ and the current net income $\left(\mathrm{NI}_{\mathrm{it}}\right)$ minus the current dividend payment $\left(\mathrm{DIV}_{\mathrm{it}}\right)$. Formally, considering this second definition $\widetilde{\mathrm{K}}_{\mathrm{it}-1}$ is computed as follows:

$$
\widetilde{\mathrm{K}}_{\mathrm{it}-1}=\mathrm{K}_{\mathrm{it}-1}+\mathrm{NI}_{\mathrm{it}}-\mathrm{DIV}_{\mathrm{it}}
$$

\footnotetext{
${ }^{11}$ Note that in this study, active adjustment in bank capital refers to equity issues/repurchases solely and excludes the change in dividend policy (payout ratio). Our aim is to focus on external capital adjustment.
} 
By dividing both sides of equation (1) by $A_{i t}$, we specify the capital partial adjustment model as follows:

$$
\mathrm{ADE}_{\mathrm{it}}=\lambda \mathrm{TDE}_{\mathrm{it}}+\epsilon_{\mathrm{it}}
$$

Where: $\mathrm{ADE}_{\mathrm{it}}=\frac{\mathrm{K}_{\mathrm{it}}}{\mathrm{A}_{\mathrm{it}}}-\frac{\widetilde{\mathrm{K}}_{\mathrm{it}-1}}{\mathrm{~A}_{\mathrm{it}}}$, the Actual Deviation and $\mathrm{TDE}_{\mathrm{it}}=\left(\frac{\mathrm{K}_{\mathrm{it}}}{\mathrm{A}_{\mathrm{it}}}\right)^{*}-\frac{\widetilde{\mathrm{K}}_{\mathrm{it}-1}}{\mathrm{~A}_{\mathrm{it}}}$, the Target Deviation.

\subsection{Ownership Augmented Capital Adjustment Model}

To test our hypotheses, we allow the capital adjustment speed ( $\lambda$ ) in equation (3) to be asymmetric with regards to upward and downward adjustments depending on the presence or the absence of a deviation between the ultimate owner's control and ownership. We therefore specify the following estimation model:

$$
\mathrm{ADE}_{\mathrm{it}}=\left(\lambda+\theta \mathrm{BELOW}_{\mathrm{it}-1}+\lambda^{\prime} \mathrm{W}_{\mathrm{i}}+\theta^{\prime} \mathrm{BELOW}_{\mathrm{it}-1} \mathrm{~W}_{\mathrm{i}}\right) \mathrm{TDE}_{\mathrm{it}}+\epsilon_{\mathrm{it}}
$$

Where BELOW $\mathrm{it}-1_{1}$ is a dummy variable equal to one if the bank needs to increase capital or decrease its assets (risk-weighted assets) to move toward the target, and zero otherwise. $\mathrm{W}_{\mathrm{i}}$ is a dummy variable equal to one if the bank is controlled by a shareholder with a gap between voting and cash-flow rights, and zero otherwise.

The parameters $\lambda$ and $\lambda+\theta$ refer to banks with no divergence between control and ownership $\left(\mathrm{W}_{\mathrm{i}}=0\right)$. They measure the proportion of capital used to adjust to the target either downwards $\left(\right.$ BELOW $\left._{\mathrm{it}-1}=0\right)$ or upwards $\left(\right.$ BELOW $\left._{\mathrm{it}-1}=1\right)$. Consistent with hypothesis (H1.a), we expect the parameters $\lambda$ and $\lambda+\theta$ to be positive and significant. If there is no fear of control/ownership dilution consistent with hypothesis H1.b we expect the coefficient $\theta$ to be non-significantly different from zero, i.e. such banks devote the same proportion of capital to adjust to the target upwards and downwards. The coefficients $\lambda+\lambda^{\prime}$ and $\lambda+\theta+\lambda^{\prime}+\theta^{\prime}$ respectively correspond to downward and upward adjustment rates of banks with controlownership wedge $\left(\mathrm{W}_{\mathrm{i}}=1\right)$. Consistent with hypothesis $(\mathrm{H} 2)$, we expect the coefficient $\lambda^{\prime}$ to be statistically non-significant, i.e. banks with and without deviation between both rights adjust their capital at the same rate when they need to reduce it. If the controlling shareholder with control-ownership wedge fears the dilution of her/his control power, according to hypothesis (H3) the coefficient $\theta^{\prime}$ is expected to be negative and significant. In the extreme case, the sum $\lambda+\theta+\lambda^{\prime}+\theta^{\prime}$ could be equal to zero which would mean that banks with control-ownership wedge do not at all increase their capital to move to the target level. 
Table B.1 in appendix B summarizes the expected sign and the relative magnitude of the adjustment speed under each case.

\subsection{Estimating the Target Capital Ratio}

We recall that $\left(\frac{K_{\mathrm{it}}}{\mathrm{A}_{\mathrm{it}}}\right)^{*}$ in equation (1) is not observable. Thus estimating the target capital ratio $\left(\frac{\mathrm{K}_{\mathrm{it}}}{\mathrm{A}_{\mathrm{it}}}\right)^{*}$ is a prerequisite to our analysis. We use several proxies to obtain fitted values of $\left(\frac{K_{i t}}{A_{i t}}\right)^{*}$.

First, we use the following partial adjustment model:

$$
\mathrm{k}_{\mathrm{it}}=\gamma \beta \mathrm{X}_{\mathrm{it}-1}+(1-\gamma) \mathrm{k}_{\mathrm{it}-1}+\eta_{\mathrm{it}}
$$

Where $\mathrm{k}_{\mathrm{it}}$ is the book value of Tier 1 regulatory capital $\left(\mathrm{K}_{\mathrm{it}}\right)$ divided by either total assets (T1_TA) or risk-weighted assets (T1_RWA). $\beta$ is the vector of coefficients to be estimated. $\gamma$ is the speed of adjustment. $\mathrm{k}_{\mathrm{it}-1}$ is the lagged Tier 1 capital ratio and $\eta_{\mathrm{it}}$ is the error term. $\mathrm{X}_{\mathrm{it}-1}$ is the matrix of a set of observable variables commonly used in the previous literature on the determinants of optimal bank capital ratios. Table C.1 in Appendix C describes these variables.

Second, we estimate $\left(\frac{\mathrm{K}_{\mathrm{it}}}{\mathrm{A}_{\mathrm{it}}}\right)^{*}$ considering the following complete adjustment model:

$$
\mathrm{k}_{\mathrm{it}}=\alpha \mathrm{X}_{\mathrm{it}-1}+\mu_{\mathrm{it}}
$$

Where $\mu_{\mathrm{it}}$ is the error term.

\section{Results}

In this study, we aim to test for the presence of potential asymmetries in banks' capital adjustment depending on their ownership structure. We proceed in two steps. In the first step, we estimate the target capital ratio $\left(\frac{\mathrm{K}_{\mathrm{it}}}{\mathrm{A}_{\mathrm{it}}}\right)^{*}$. For this purpose, we use two models: a partial and a complete adjustment model. We estimate the partial adjustment model specified in equation (5) using the Generalized Method of Moments (GMM) estimator developed for dynamic models by (Arellano \& Bond, 1991). The complete adjustment model specified in equation (6) is estimated using random effects estimator. The results obtained for this first step are 
reported in Table 5. Table D.1 in appendix D reports the correlation matrix of the explanatory variables used in this step. On the whole, the correlation coefficients are low. To deal with multi-colinearity issues, we orthogonalize the natural logarithm of assets (LN_TA) on charter value $(\mathrm{CV})$ and the return on assets (ROA) on the cost of equity (COST_EQ).

\section{[Insert Table 5 about here]}

In the second step, we replace in equation (4) the target capital ratio $\left(\frac{K_{i t}}{A_{i t}}\right)^{*}$ by its fitted value obtained from the first step estimation, compute both the target deviation $\left(\mathrm{TDE}_{\mathrm{it}}\right)$ and the actual deviation $\left(\mathrm{ADE}_{\mathrm{it}}\right)$ and estimate equation (4) using fixed effects estimator ${ }^{12}$. Table 6 reports the results obtained from this second step estimation. Panel A of Table 6 reports estimation results of equation (4) considering both passive and active components of bank capital. Panel B presents estimation results focusing only on the active variation in Tier 1 capital.

\section{[Insert Table 6 about here]}

We first interpret the results in Panel $\mathrm{B}$. The parameters estimates $\lambda$ and $\lambda+\theta$ are both positive and highly significant. They range from 0.37 to 0.43 and from 0.39 to 0.47 respectively. As expected, the coefficient $\theta$ of the interaction term $\mathrm{TDE}_{\mathrm{it}} \times \mathrm{BELOW}_{\mathrm{it}-1}$ is statistically non-significant. These results confirm the predictions of hypotheses H1.a and H1.b. Banks controlled by a shareholder with equal rights adjust their capital upwards $(\lambda+\theta)$ and downwards $(\lambda)$ at the same rate $(\theta=0)$. Such banks actively manage their capital and fill almost half of the required change in capital through equity issues/repurchases. For banks controlled by a shareholder with a gap between both rights, the parameter estimate $\lambda+\lambda^{\prime}$ (downward adjustment) is highly significant and ranges from 0.33 to 0.48 , while the parameter estimate $\lambda+\theta+\lambda^{\prime}+\theta^{\prime}$ (upward adjustment) is significantly lower (between 0.04 and 0.09). The Wald-test indicates that the latter is statistically non-significant. Consistent with hypothesis H2, such banks adjust their capital identically to banks without controlownership gap $\left(\lambda^{\prime}=0\right)$ when they need to repurchase equity. Conversely, such banks are reluctant to actively adjust their position when they have to issue equity, possibly because of the fear of control dilution.

\footnotetext{
${ }^{12}$ We favor this estimator because previous studies (Gropp \& Heider, 2011) argue that fixed effects contribute to explain the adjustment speed. We also perform the regressions using OLS and Random Effects estimators. The results, not reported here, are almost similar.
} 
Regarding Panel A of Table 6 (both active and passive changes in bank capital) the results again show that banks controlled through equal rights (voting and cash-flow) symmetrically adjust their capital upwards and downwards $(\lambda$ and $\lambda+\theta$ are both positive and significant, $\theta$ is statistically non-significant). Banks controlled via discrepancy between both rights adjust their capital upwards $\left(\lambda+\theta+\lambda^{\prime}+\theta^{\prime}\right)$ and downwards $\left(\lambda+\lambda^{\prime}\right)$ although the upward adjustment rate is lower (24\%-34\% versus $42 \%-55 \%$ for downward adjustment). This finding suggests that such banks counterbalance their reluctance to actively adjust their capital upwards by passively managing their capital (i.e. earnings retention or a decrease in dividend payment).

In summary, the results show that the dynamics of bank Tier 1 capital are actually influenced by the presence or absence of a deviation between the ultimate owner's voting and cash-flow rights. Banks with equal rights of the ultimate owner are found to adjust their capital at the same rate regardless of their initial position (below or above the target level). Conversely, banks with deviation between voting and cash-flow rights significantly adjust their capital only when they need to reduce it to move closer to the target level. When the adjustment process requires an increase in capital, such banks tend to passively adjust their position, possibly because of the fear of control dilution. Our findings also indicate that such "specific" banks prevail in Europe (around 50\% of the banks in our sample are controlled through deviation between both rights). Such institutions rely more on traditional intermediation activities (loans), and contribute up to $50 \%$ of total loans granted to the economy as a whole ${ }^{13}$. Our results suggest that to preserve their control, banks with divergence between voting and cash-flow rights are reluctant to actively manage their Tier 1 regulatory capital upwards. Given this finding, we presume that such a behavior might be more pronounced under Basel III as the Basel Committee has narrowed the definition of Tier 1 capital to ordinary shares only. Because such banks are less able to actively adjust their Tier 1 capital without incurring changes in voting rights, they might increase their reliance on passive adjustments and asset downsizing. Given their prevalence in Europe and their important contribution to the economy as major lenders our findings have important policy implications.

\footnotetext{
${ }^{13}$ For more details se table E.1 in appendix E.
} 


\section{Deeper Investigation and Robustness Checks}

In this section, we first make some extensions to go deeper in our investigation and then carry out some robustness checks.

\subsection{Extensions}

Our main results support the conjecture that controlling shareholders with deviation between voting and cash-flow rights avoid recapitalization to preserve their control. We now go further by analyzing the conditions under which the fear of control dilution is more or less pronounced. We consider shareholder type and shareholder protection.

\section{Capital Adjustment and Ultimate Controlling Shareholder Type}

The fear of control dilution may be stronger if the controlling shareholder is a family or a state and weaker if the controlling shareholder is a bank or other categories. The literature argues that the deviation between both rights attracts families and states if these expect diverting higher resources (Almeida \& Wolfenzon, 2006). Cronqvist and Nilsson (2005) find that family-controlled firms avoid equity issuing methods that may dilute their control benefits or impose more monitoring on them. Thus, family and state controlled banks are expected to have significant incentives to influence capital adjustment decisions that could threaten their control position.

To test this hypothesis, we split the full sample into two subsamples based on the type of the controlling shareholder. We isolate family and state ownership from other categories (BANK, OTHER). We run regressions separately on the two subsamples. The results regarding the estimation of the target capital ratio, not reported here, are similar to those previously obtained. The results for the adjustment speed on both subsamples are presented in Table 7.1 and Table 7.2. For the subsample of banks controlled by a family or a state (Table 7.1), the findings are almost similar to those previously obtained, i.e. unlike banks controlled by a shareholder with equal rights, banks controlled by a shareholder with a gap between both rights differently weigh increases and decreases in capital. Regarding the subsample of banks controlled by a bank or any other category (different from a family and a state), again, banks with no gap between both rights do not distinguish between increases and decreases in capital and adjust their capital in both cases. However, unlike the results obtained on the previous subsample (family or state), banks with deviation between VR and CFR adjust their capital 
both upwards and downwards although the upward adjustment rate is lower. The results in Panel B of Table 7.2 show that the adjustment rate for such banks when they face a shortage in capital ranges from $10 \%$ to $20 \%$. The Wald test indicates that this capital adjustment is significantly different from zero (except in column (1) Eq.6). These results are consistent with our predictions that family and state ultimate owners have stronger incentives protect their control compared to other categories.

\section{Capital Adjustment and Shareholder Protection}

We further test how shareholder protection rights may affect the relationship between capital adjustment and ownership structure. Expropriation is more likely to occur in countries with weak shareholder protection (La Porta et al., 2002). Hence, we conjecture that the controlling shareholder with different VR and CFR might be more reluctant to raise equity in countries with low shareholder protection. This is because control in such countries is more valuable in the sense that a controlling owner can divert significant resources and protect herself/himself from becoming a minority shareholder and suffer expropriation.

To examine this hypothesis, we again split the full sample into two subsamples based on the cross-country median value of the shareholder protection index ${ }^{14}$. We perform regressions on these two subsamples. Estimating the target capital ratio, not reported here, again yields similar results as before. Table 8.1 and Table 8.2 illustrate respectively the estimation of equation (4) for the subsamples with weak and strong shareholder protection. The results reported in Table 8.1 confirm those previously obtained. Banks controlled through equal rights adjust their capital upwards and downwards at the same rate. However, in the presence of a gap between both rights, banks do adjust their capital downwards but are reluctant to adjust it upwards. The results shown in Table 8.2 indicate that banks with deviation between VR and CFR and established in countries with good shareholder protection adjust their capital even when they face a capital shortage. This result is consistent with our prediction: in countries with good shareholder protection the fear of control dilution is tempered, consequently banks with deviation between voting and cash-flow rights adjust their capital ratio upwards and downwards even though downward adjustment rate is higher.

\footnotetext{
${ }^{14}$ We consider the shareholder protection index as calculated in (La Porta et al., 1998).
} 


\subsection{Sensitivity analysis}

We perform several regressions to check the robustness of our results. Appendix F reports the estimation results ${ }^{15}$.

First, we carry out the following robustness checks, still considering the control threshold of $10 \%$.

We focus on the sample of controlled banks, i.e. we exclude from the initial sample 40 widely-held banks. This criterion leaves us with 402 European controlled banks. Regression results are shown in Table F.1. Then, we restrict our sample to listed banks. The results are shown in

Table F.2. In addition, we consider only a pre-crisis period and re-estimate the whole process for the 2002-2006 period. The estimation results are reported in Table F.3. Furthermore, we exclude from the initial sample observations for which the Tier 1 risk-based capital ratio is below the regulatory minimum ratio (4\%). The results are shown in Table F.4. Finally, we re-estimate the target capital ratio considering the dummy variable that reflects the presence or absence of a gap between control and ownership $\left(\mathrm{W}_{\mathrm{i}}\right)$. This check is motivated by our finding that on average banks without a gap between both rights hold higher Tier 1 capital ratios than their counterparts (see table 4). The results obtained for the second step estimations are reported in Table F.5.

In all cases, the results are consistent with those previously obtained for both steps.

Second, we change the control threshold and re-estimate all the regressions considering this new control level. We recalculate ownership variables considering a control level of $20 \%$ instead of $10 \%$. This new minimum control threshold changes our database both quantitatively and qualitatively (see Table 3). First, we add some of the banks for which we fail to follow the track until the ultimate owner when we use a $10 \%$ control level. Accordingly, 22 banks $^{16}$ are added to our sample reaching 464 banks corresponding to 2647 observations. In addition, the structure of the initial sample has changed. The number of widely-held banks increases from 40 to 66 (178 additional observations). Furthermore, the nature of the ultimate owner is modified. For example, the number of family or state

\footnotetext{
${ }^{15}$ Note that in each case we re-estimate the target capital ratio (step 1) using the considered sample. The results, not reported here, are available on request. The results are almost identical for each sub-sample.

${ }^{16} \mathrm{We}$ are not able to end the process for 28 banks when we consider the $10 \%$ control threshold and for 6 banks with the $20 \%$ threshold.
} 
controlled banks diminishes by 30 whereas the number of banks controlled by a bank increases by 46 .

Table F.6 reports the estimation results when we use this new control threshold. The results remain unchanged and are consistent with those previously obtained.

We also check the robustness of our results by performing further estimations using this new control threshold (20\%). We consider the following samples (1) Controlled banks (2) Listed banks (3) 2002-2006 period and (4) Banks above the regulatory capital minimum. In all cases, our main results -not reported here- remain unchanged.

\section{Conclusion and Policy Implications}

The purpose of this study is to empirically test whether bank ownership characteristics, especially the separation between voting and cash-flow rights affect the bank's decision to recapitalize. We specifically question whether banks with and without separation between both rights behave differently when they face a shortage or a surplus in capital. For this purpose, we assemble a novel hand-collected dataset on bank ultimate control and ownership structure and work on an unbalanced panel of 442 commercial banks across 17 European countries over the 2002-2010 period.

On the whole, the results confirm the conjecture that the dynamics of equity capital, that is its adjustment to the target level, is different for banks controlled by a shareholder with or without deviation between voting and cash-flow rights. On the one hand, when there is no gap between both rights, banks equally adjust their capital upwards or downwards and do not appear to fear control dilution. On the other hand, when there is deviation between both rights, banks differently weigh the need to increase or decrease equity. They are reluctant to actively adjust their capital upwards to reach the target level. Our findings suggest that controlling shareholders with divergence between both rights curb recapitalization to preserve their control position and encourage equity repurchase to strengthen their voting power.

Our findings have several policy implications. We show that during the 2002-2010 period covered by the Basel I and II accords, European banks with and without deviation between voting and cash-flow rights of the ultimate owner behave differently when they adjust their Tier 1 regulatory capital to move to the target level. Consequently it is important for regulators and supervisors to consider that changes in capital requirements, particularly narrowing the definition of Tier 1 capital to ordinary shares, might impact banks differently 
depending on their ownership pattern. According to our results, banks controlled by a shareholder with divergence between both rights are reluctant to raise equity that may dilute the voting power. Consequently, we presume that the propensity to adjust their Tier 1 capital ratio through alternative methods (i.e. reduce their dividend payment, proceed to downward adjustment in asset size or risk-weighted assets) other than raising equity might be higher under Basel III schemes because such banks have not only to raise new equity but also to use ordinary shares which, unlike preferred shares (in general carrying only cash-flow rights), may dilute the voting rights of the controlling shareholder. Hence, credit crunch phenomena are more likely to occur in the transition from Basel II to Basel III which is supposed to be completed in 2019. Such banks should be closely monitored by regulators and supervisors. A better disclosure of banks' ownership structures following the recommendations of the Basel Committee on Banking Supervision (BIS, 2010b) should be encouraged to improve regulatory but also market monitoring and discipline. 


\section{References}

Almeida, H., Park, S.Y., Subrahmanyam, M.G. \& Wolfenzon, D., 2011. The Structure and Formation of Business Groups: Evidence from Korean Chaebols. Journal of Financial Economics, 99(2), pp.44775.

Almeida, H. \& Wolfenzon, D., 2006. A Theory of Pyramidal Ownership and Family Business Groups. Journal of Finance, 61(6), pp.2637-81.

Altinkihc, O. \& Hansen, R.S., 2000. Are There Economies of Scale in Underwriting Fees? Evidence of Rising External Financing Costs. Review of Financial Studies, 13(1), pp.191-218.

Arellano, M. \& Bond, S., 1991. Some Tests of Specification for Panel Data: Monte Carlo Evidence and an Application to Employment Equations. Review of Economic Studies, 58(2), pp.277-97.

Ayuso, J., Perez, D. \& Saurina, J., 2004. Are capital buffers pro-cyclical?: Evidence from Spanish panel data. Journal of Financial Intermediation, 13(2), pp.249-64.

Azofra, V. \& Santamaria, M., 2011. Ownership, control, and pyramids in Spanish commercial banks. Journal of Banking and Finance, 35(6), p.1464-1476.

Bank of International Settlements, 2010a. Group of Governors and Heads of Supervision announces higher global minimum capital standards. Consultative Document.

Bank of International Settlements, 2010b. Principles for enhancing bank corporate governance. Consultative Document.

Barth, J., Caprio, G. \& Levine, R., 2004. Bank regulation and supervision: what works best? Journal of Financial Intermediation, 13(2), pp.205-48.

Bebchuk, L., Kraakman, R. \& Triantis, G., 2000. Stock Pyramids, Cross-Ownership, and Dual Class Equity: The Creation and Agency Costs of Separating Control From Cash-Flow Rights. In: Concentrated Corporate Ownership (R. Morck, ed.), 460(249), pp.445-60.

Bennedsen, M. \& Wolfenzon, D., 2000. The balance of power in closely held corporations. Journal of Financial Economics, 58(1-2), pp.113-39.

Berger, A.N. et al., 2008. How Do Large Banking Organizations Manage their capital ratios? Journal of Financial Services Research, 34(2), p.123-149.

Berger, A.N., Herring, R.J. \& Szegö, G.P., 1995. The Role of Capital in Financial Institutions. Journal of Banking and Finance, 19(3-4), pp.393-430.

Boubakri, N. \& Ghouma, H., 2010. Control/ownership structure, creditor rights protection, and the cost of debt financing: International evidence. Journal of Banking and Finance, 34(10), p.2481-2499.

Brewer, E., Kaufman, G.G. \& Wall, L.D., 2008. Bank Capital Ratios Across Countries: Why Do They Vary? Journal of Financial Services Research, 34(2), pp.177-201.

Burkart, M., Gromb, D. \& Panunzi, F., 1998. Why Higher Takeover Premia Protect Minority Shareholders. Journal of Political Economy, 106(1), pp.172-204.

Byoun, S., 2008. How and When Do Firms Adjust Their Capital Structures Toward Targets? Journal of Finance, 63(6), pp.3069-96.

Caprio, G., Laeven, L. \& Levine, R., 2007. Governance and bank valuation. Journal of Financial Intermediation, 16(4), p.584-617. 
Claessens, S., Djankov, S., Fan, J.P.H. \& Lang, L.H.P., 2002. Disentangling the Incentive and Entrenchment Effects of Large Shareholdings. Journal of Finance, 57(6), pp.2741-71.

Claessens, S., Djankov, S. \& Lang, L.H.P., 2000. The separation of ownership and control in East Asian Corporations. Journal of Financial Economics, 58(1-2), pp.81-112.

Cronqvist, H. \& Nilsson, M., 2005. The choice between rights offerings and private equity placements. Journal of Financial Economics, 78(2), pp.375-407.

Faccio, M. \& Lang, L.H.P., 2002. The ultimate ownership of Western European corporations. Journal of Financial Economics, 65(3), p.365-395.

Faccio, M., Lang, L.H.P. \& Young, L., 2001. Dividends and Expropriation. American Economic Review, 91(1), pp.54-78.

Flannery, M.J. \& Rangan, K.P., 2006. Partial adjustment toward target capital structures. Journal of Financial Economics, 79(3), p.469-506.

Flannery, M.J. \& Rangan, K.P., 2008. What Caused the Bank Capital Build-Up of the 1990s? Review of Finance, 12(2), pp.391-429.

Fonseca, A.R. \& González, F., 2010. How bank capital buffers vary across countries: The influence of cost of deposits, market power and bank regulation. Journal of Banking and Finance, 34(4), p.892902.

Gomes, A. \& Novaes, W., 2001. Sharing of Control as a Corporate Governance Mechanism. PIER Working Paper.

Gropp, R. \& Heider, F., 2011. The determinants of bank capital structure. Review of Finance, 15, pp.29-74.

Harris, M. \& Raviv, A., 1988. Corporate governance : Voting rights and majority rules. Journal of Financial Economics, 20(1-2), pp.203-35.

Haw, I.-M., Ho, S.S.M. \& Hu, B., 2010. Concentrated control, institutions, and banking sector: An international study. Journal of Banking and Finance, 34(3), p.485-497.

Hyun, J.-S. \& Rhee, B.-K., 2011. Bank capital regulation and credit supply. Journal of Banking and Finance, 35(2), pp.323-30.

Ivashina, V. \& Scharfstein, D., 2010. Bank Lending During the Financial Crisis of 2008. Journal of Financial Economics, 97(3), pp.319-38.

Jacques, K. \& Nigro, P., 1997. Risk-based capital, portfolio risk, and bank capital: a simultaneous equation approach. Journal of Economics and Business, 49(6), pp.533-47.

Jokipii, T. \& Milne, A., 2008. The cyclical behaviour of European bank capital buffers. Journal of Banking and Finance, 32(8), p.1440-1451.

Jokipii, T. \& Milne, A., 2011. Bank capital buffer and risk adjustment decisions. Journal of Financial Stability, 7(3), p.165-178.

Keeley, M.C., 1990. Deposit insurance, risk, and market power in banking. American Economic Review, 80(5), pp.1183-200.

La Porta, R., Lopez-de-Silane, F., Shleifer, A. \& Vishny, R.W., 1998. Law and Finance. Journal of Political Economy, 106(6), pp.1113-55.

La Porta, R., Lopez-de-Silanes, F. \& Shleifer, A., 1999. Corporate Ownership around the World. Journal of Finance, 54(2), pp.471-517.

La Porta, R., Lopez-de-Silanes, F. \& Shleifer, A., 2002. Investor Protection and Corporate Valuation. Journal of Finance, 57(3), pp.1147-70. 
Laderman, E.S., 1994. Wealth effects of bank holding company securities issuance and loan growth under the risk-based capital requirements. Economic Review, 2, pp.30-41.

Laeven, L. \& Levine, R., 2008. Complex Ownership Structures and Corporate Valuations. Review of Financial Studies, 21(2), pp.579-604.

Laeven, L. \& Levine, R., 2009. Bank governance,regulation and risk taking. Journal of Financial Economics, 93(2), p.259-275.

Lin, C., Ma, Y., Malatesta, P. \& Xuan, Y., 2011. Ownership structure and the cost of corporate borrowing. Journal of Financial Economics, 100(1), pp.1-23.

Marcus, A.J., 1983. The Bank Capital Decision: A Time Series--Cross Section Analysis. Journal of Finance, 38(4), pp.1217-32.

Maury, B. \& Pajuste, A., 2005. Multiple Large Shareholders and Firm Value. Journal of Banking and Finance, 29(7), pp.1813-34.

Memmel, C. \& Raupach, P., 2010. How Do Banks Adjust Their Capital Ratios? Journal of Financial Intermediation, 19(4), pp.509-28.

Myers, S.C., 1977. Determinants of Corporate Borrowing. Journal of Financial Economics, 5(2), pp.147-75.

Myers, S.C. \& Majluf, N.S., 1984. Corporate financing and investment decisions when firms have information that investors do not have. Journal of Financial Economics, 13(2), p.187-221.

Nier, E. \& Baumann, U., 2006. Market discipline, disclosure and moral hazard in banking. Journal of Financial Intermediation, 15(3), pp.332-61.

Pagano, M. \& Röell, A., 1998. The Choice Of Stock Ownership Structure: Agency Costs, Monitoring, And The Decision To Go Public. The Quarterly Journal of Economics, 113(1), pp.187-225.

Peek, J. \& Rosengren, E.S., 1997. How well capitalized are well-capitalized banks? New England Economic Review, 19, pp.41-51.

Peura, S. \& Keppo, J., 2006. Optimal Bank Capital with Costly Recapitalization. Journal of Business, 79(4), pp.2163-201.

Prowse, S., 1995. Alternative methods of corporate control in commercial banks. Economic and Financial Policy Review, pp.24-36.

Rime, B., 2001. Capital requirements and bank behaviour: Empirical evidence for Switzerland. Journal of Banking and Finance, 25(4), pp.789-805.

Shehzad, C.T., Haan, J.d. \& Scholtens, B., 2010. The impact of bank ownership concentration on impaired loans and capital adequacy. Journal of Banking and Finance, 34(2), p.399-408.

Shleifer, A. \& Wolfenzon, D., 2002. Investor protection and equity markets. Journal of Financial Economics, 66(1), pp.3-27.

Stulz, R., 1988. Managerial control of voting rights : Financing policies and the market for corporate control. Journal of Financial Economics, 20(1-2), pp.25-54. 


\section{Table 1}

Distribution of European Commercial Banks and Representativeness of the Sample

\begin{tabular}{|c|c|c|c|c|c|}
\hline \multirow{2}{*}{ Country } & \multicolumn{2}{|c|}{ Banks available in Bankscope } & \multicolumn{3}{|c|}{ Banks in the final sample } \\
\hline & All Banks & Listed Banks & All Banks & Listed Banks & Per cent $^{a}$ \\
\hline Austria & 88 & 5 & 18 & 3 & 42.81 \\
\hline Belgium & 50 & 2 & 11 & 1 & 98.43 \\
\hline Denmark & 61 & 42 & 45 & 35 & 93.80 \\
\hline Finland & 10 & 2 & 3 & 0 & 82.72 \\
\hline France & 191 & 18 & 25 & 6 & 79.42 \\
\hline Germany & 208 & 20 & 30 & 9 & 74.83 \\
\hline Greece & 19 & 11 & 13 & 9 & 96.47 \\
\hline Ireland & 35 & 5 & 15 & 4 & 96.70 \\
\hline Italy & 188 & 27 & 128 & 17 & 86.92 \\
\hline Luxembourg & 107 & 4 & 18 & 4 & 53.93 \\
\hline Netherlands & 47 & 5 & 22 & 4 & 63.02 \\
\hline Norway & 20 & 4 & 8 & 3 & 73.85 \\
\hline Portugal & 27 & 5 & 11 & 2 & 84.70 \\
\hline Spain & 92 & 17 & 18 & 10 & 91.71 \\
\hline Sweeden & 25 & 2 & 13 & 2 & 83.32 \\
\hline Switzerland & 182 & 7 & 15 & 3 & 87.21 \\
\hline United Kingdom & 183 & 9 & 49 & 5 & 72.16 \\
\hline Total & 1533 & 185 & 442 & 117 & - \\
\hline
\end{tabular}

${ }^{a}$ is the percentage of total assets of all commercial banks in our sample in the aggregate total assets of all commercial banks provided by Bankscope in a given country over the 2002-2010 period. 


\section{$\underline{\text { Table } 2}$}

General Descriptive Statistics, on average over the 2002-2010 period

\begin{tabular}{|c|c|c|c|c|c|c|c|c|c|c|c|}
\hline & TA & DEP_TA & TF_TA & LO_TA & $\mathbf{L L P}$ & EQ_TA & TCR & T1_RWA & ROA & ROE & MARG_TA \\
\hline \multicolumn{12}{|c|}{ Full sample of commercial banks in Bankscope (1533 banks) } \\
\hline Mean & 25268.59 & 69.31 & 80.45 & 47.92 & 0.73 & 14.25 & 19.95 & 17.00 & 0.70 & 6.89 & 1.22 \\
\hline Median & 1037.50 & 76.26 & 87.38 & 51.32 & 0.35 & 8.16 & 13.13 & 10.55 & 0.52 & 6.58 & 0.15 \\
\hline Std. Dev. & 120352.05 & 23.07 & 21.58 & 30.22 & 2.07 & 17.48 & 33.50 & 32.80 & 3.78 & 14.11 & 4.04 \\
\hline Minimum & 0.10 & 0.00 & 0.00 & 0.00 & -19.23 & 0.00 & 0.10 & -0.40 & -56.54 & -97.35 & -14.56 \\
\hline Maximum & 2202423 & 150.18 & 850.00 & 99.96 & 17.81 & 100.00 & 877.00 & 753.00 & 75.50 & 79.77 & 48.91 \\
\hline \multicolumn{12}{|c|}{ Final sample of commercial banks (442 banks) } \\
\hline Mean & 72333.56 & 65.38 & 85.57 & 55.18 & 0.77 & 9.16 & 14.33 & 12.34 & 0.60 & 7.20 & 0.54 \\
\hline Median & 4864.10 & 68.86 & 88.13 & 60.75 & 0.47 & 6.74 & 12.50 & 10.10 & 0.52 & 8.24 & 0.04 \\
\hline Std. Dev. & 213529.13 & 20.15 & 11.12 & 26.09 & 1.51 & 9.22 & 6.47 & 7.10 & 1.77 & 12.68 & 2.55 \\
\hline Minimum & 6.90 & 0.00 & 0.00 & 0.00 & -19.23 & 0.00 & 0.10 & 0.10 & -15.04 & -90.70 & -0.51 \\
\hline Maximum & 2202423 & 94.93 & 99.31 & 99.07 & 17.13 & 95.95 & 50.00 & 36.05 & 19.65 & 79.77 & 28.95 \\
\hline
\end{tabular}

All variables are expressed in percentage except TA which is in million Euros. TA is the bank's total asset. DEP TA is the ratio of total deposits to total assets. TF TA is the ratio of total funding to total asset. LO_TA is the ratio of net loans to total asset. LLP is the ratio of loan loss provisions to net loans. EQ_TA is the ratio of total equity to total asset. TCR is the risk-based total capital ratio. T1_RWA is the risk-based Tier 1 capital ratio. ROA is the return on asset. ROE is the return on equity. MARG_TA is the ratio of net interest margin to total asset. 


\section{$\underline{\text { Table } 3}$}

\section{Ultimate Ownership of European Commercial Banks}

\begin{tabular}{|c|c|c|c|c|c|c|c|c|c|c|c|c|}
\hline & \multicolumn{6}{|c|}{ PANEL A: Control Threshold 10\% } & \multicolumn{6}{|c|}{ PANEL B: Control Threshold 20\% } \\
\hline & \multicolumn{2}{|c|}{ WHOLE SAMPLE } & \multicolumn{2}{|c|}{$V R=C F R$} & \multicolumn{2}{|c|}{$\mathbf{V R} \neq \mathbf{C F R}$} & \multicolumn{2}{|c|}{ WHOLE SAMPLE } & \multicolumn{2}{|c|}{$V R=C F R$} & \multicolumn{2}{|c|}{$\mathbf{V R} \neq \mathbf{C F R}$} \\
\hline & (a) & (b) & (a) & (b) & (a) & (b) & (a) & (b) & (a) & (b) & (a) & (b) \\
\hline WIDELY & $\begin{array}{l}11.54 \\
(297)\end{array}$ & 40 & - & - & - & - & $\begin{array}{l}17.94 \\
(475)\end{array}$ & 66 & - & - & - & - \\
\hline CONTROLLED & $\begin{array}{l}88.46 \\
(2277)\end{array}$ & 402 & $\begin{array}{l}55.78 \\
(1270)\end{array}$ & 215 & $\begin{array}{l}44.22 \\
(1007)\end{array}$ & 187 & $\begin{array}{l}82.06 \\
(2172)\end{array}$ & 398 & $\begin{array}{l}57.41 \\
(1247)\end{array}$ & 225 & $\begin{array}{l}42.59 \\
(925)\end{array}$ & 173 \\
\hline BANK & $\begin{array}{l}38.29 \\
(872)\end{array}$ & 155 & $\begin{array}{l}53.46 \\
(679)\end{array}$ & 119 & $\begin{array}{l}19.16 \\
(193)\end{array}$ & 36 & $\begin{array}{l}51.70 \\
(1123)\end{array}$ & 201 & $\begin{array}{l}64.15 \\
(800)\end{array}$ & 144 & $\begin{array}{l}34.91 \\
(323)\end{array}$ & 57 \\
\hline FAMILY & $\begin{array}{l}21.82 \\
(497)\end{array}$ & 90 & $\begin{array}{l}17.16 \\
(218)\end{array}$ & 38 & $\begin{array}{l}27.70 \\
(279)\end{array}$ & 52 & $\begin{array}{l}16.94 \\
(368)\end{array}$ & 73 & $\begin{array}{l}13.15 \\
(164)\end{array}$ & 31 & $\begin{array}{l}22.05 \\
(204)\end{array}$ & 42 \\
\hline STATE & $\begin{array}{l}14.84 \\
(338)\end{array}$ & 65 & $\begin{array}{l}7.16 \\
(91)\end{array}$ & 14 & $\begin{array}{l}24.52 \\
(247)\end{array}$ & 51 & $\begin{array}{l}11.74 \\
(255)\end{array}$ & 52 & $\begin{array}{l}6.09 \\
(76)\end{array}$ & 13 & $\begin{array}{l}19.35 \\
(179)\end{array}$ & 39 \\
\hline OTHER & $\begin{array}{l}25.05 \\
(570)\end{array}$ & 92 & $\begin{array}{l}22.22 \\
(282)\end{array}$ & 44 & $\begin{array}{l}28.62 \\
(288)\end{array}$ & 48 & $\begin{array}{l}19.62 \\
(426)\end{array}$ & 72 & $\begin{array}{l}16.61 \\
(207)\end{array}$ & 37 & $\begin{array}{l}23.69 \\
(219)\end{array}$ & 35 \\
\hline $\begin{array}{c}\text { Total } \\
\text { observations/banks }\end{array}$ & 2574 & 442 & 1270 & 215 & 1007 & 187 & 2647 & 464 & 1247 & 225 & 925 & 173 \\
\hline
\end{tabular}

This table reports Ultimate Ownership Structure for European commercial banks using a minimum control threshold of 10\% (PANEL A) and 20\% (PANEL B) for the whole sample (WHOLE SAMPLE) and the subsamples of banks controlled by a shareholder with equal voting and cash-flow rights (VR=CFR) and different rights (VR $\neq$ CFR). In columns (a), we report the percentage and the number of observations (between brackets) for each ownership category. In columns (b), we present the corresponding number of banks. WIDELY is a dummy variable equal to one if the bank is widely-held, and zero otherwise. CONTROLLED is a dummy variable equal to one if the bank is controlled by at least one shareholder, and zero otherwise. BANK is a dummy variable equal to one if the bank is controlled by a bank, and zero otherwise. FAMILY is a dummy variable equal to one if the bank is controlled by a family/individual, and zero otherwise.

STATE is a dummy variable equal to one if the bank is controlled by a state/public authority, and zero otherwise. OTHER is a dummy variable equal to one if the bank is controlled by any of these categories: Industrial firm, financial and insurance companies, Mutual and Pension funds, Foundations and Research institutes, Managers or cross-holdings, and zero otherwise. 


\section{Table 4}

Summary Statistics of the main variables over the 2002-2010 period

\begin{tabular}{|c|c|c|c|c|c|c|c|c|c|c|c|c|}
\hline \multirow{2}{*}{ Variables } & \multirow{2}{*}{$\begin{array}{l}\text { Number of } \\
\text { observations }\end{array}$} & \multicolumn{5}{|c|}{ Sample VR $=$ CFR } & \multicolumn{5}{|c|}{ Sample VR $\neq$ CFR } & \multirow[t]{2}{*}{ T-test } \\
\hline & & Mean & Median & Std.Dev. & Minimum & $\overline{\text { Maximum }}$ & Mean & Median & Stan.dev & Minimum & Maximum & \\
\hline TA & 2573 & 78614.30 & 4470.70 & 238175.84 & 6.90 & 2202423 & 64463.08 & 5623.30 & 171384.27 & 50.80 & 1967121.9 & 1.63 \\
\hline LO_TA & 2563 & 52.52 & 55.98 & 24.14 & 0.00 & 98.87 & 57.46 & 62.22 & 27.99 & 0.00 & 99.07 & $-4.74 * * *$ \\
\hline ROA & 2569 & 0.64 & 0.57 & 1.79 & -15.04 & 19.65 & 0.47 & 0.45 & 1.16 & -10.60 & 7.78 & $2.64 * * *$ \\
\hline ROE & 2544 & 7.28 & 8.12 & 12.30 & -90.70 & 79.77 & 7.09 & 8.42 & 13.26 & -78.82 & 64.41 & $0.36 * * *$ \\
\hline LLP & 2436 & 0.78 & 0.49 & 1.40 & -7.32 & 17.13 & 0.74 & 0.40 & 1.66 & -19.23 & 13.33 & 0.53 \\
\hline NPL & 1714 & 3.70 & 2.23 & 4.75 & 0.00 & 67.99 & 4.26 & 2.45 & 6.32 & 0.00 & 64.04 & $-2.06 * *$ \\
\hline MKT_DISC & 2247 & 19.44 & 16.45 & 17.61 & 0.00 & 100.00 & 17.00 & 10.59 & 19.33 & 0.00 & 96.83 & $3.07 * * *$ \\
\hline DIV & 2075 & 0.92 & 1.00 & 0.27 & 0.00 & 1.00 & 0.86 & 1.00 & 0.35 & 0.00 & 1.00 & $3.59 * * *$ \\
\hline TCR & 2491 & 17.06 & 12.78 & 23.77 & 2.69 & 50.00 & 16.58 & 12.31 & 31.07 & 0.10 & 48.03 & 0.43 \\
\hline T1_RWA & 2511 & 12.71 & 10.54 & 7.45 & 1.87 & 36.05 & 11.76 & 9.68 & 6.50 & 0.10 & 34.97 & $3.28 * * *$ \\
\hline LISTED & 2574 & 0.45 & 0.00 & 0.50 & 0.00 & 1.00 & 0.21 & 0.00 & 0.41 & 0.00 & 1.00 & - \\
\hline VR & 2574 & 56.14 & 55.22 & 40.40 & 0.00 & 100.00 & 84.76 & 98.82 & 22.01 & 15.95 & 100.00 & - \\
\hline CFR & 2574 & 56.14 & 55.22 & 40.40 & 0.00 & 100.00 & 18.97 & 23.29 & 29.18 & 2.81 & 99.98 & - \\
\hline WEDGE & 2574 & 0.00 & 0.00 & 0.00 & 0.00 & 0.00 & 65.79 & 44.72 & 30.50 & 0.00 & 97.16 & - \\
\hline
\end{tabular}

This table reports summary statistics of the main variables for both subsamples of banks controlled by a shareholder with equal voting and cash-flow rights (VR=CFR) and different rights (VR $\neq \mathrm{CFR}$ ). All variables are expressed in percentage except TA which is in million euros. TA is the bank's total asset. LO TA is the ratio of net loans to total asset. ROA is the return on asset. ROE is the return on equity. LLP is the ratio of loan loss provisions to net loans. NPL is the ratio of non-performing loans to gross loans. MKT_DISC is the ratio of total long term funding to total funding. DIV is a dummy variable that takes 1 if the bank pays dividends at time t, and zero otherwise. TCR is the risk-based total capital ratio. T1_RWA is the risk-based Tier 1 capital ratio. LISTED is a dummy variable equal to one if the bank is listed, and zero otherwise. VR is the ultimate owner's voting rights. CFR is the ultimate owner's cash-flow rights. WEDGE is the difference between the ultimate owner's voting (VR) and cash-flow rights (CFR). T-test is the test of mean differences. 


\section{Table 5}

Estimating the target capital ratio for the whole sample over the 2002-2010 period

\begin{tabular}{|c|c|c|c|c|c|c|c|c|}
\hline \multirow{3}{*}{$\begin{array}{c}\text { Dependent } \\
\text { variable }\end{array}$} & \multicolumn{4}{|c|}{ T1_TA } & \multicolumn{4}{|c|}{ T1_RWA } \\
\hline & \multicolumn{2}{|c|}{$\mathrm{Eq.5}$} & \multicolumn{2}{|c|}{ Eq.6 } & \multicolumn{2}{|c|}{$\mathrm{Eq.5}$} & \multicolumn{2}{|c|}{ Eq.6 } \\
\hline & $\mathbf{a}$ & b & $\mathbf{a}$ & b & $\mathbf{a}$ & b & $\mathbf{a}$ & b \\
\hline $\mathrm{T}_{1} \mathrm{TA}_{\mathrm{t}-1}$ & $\begin{array}{l}0.59^{* * * *} \\
(0.00)\end{array}$ & $\begin{array}{l}0.60^{\text {**** }} \\
(0.00)\end{array}$ & - & - & - & - & - & - \\
\hline T1_RWA ${ }_{t-1}$ & - & - & - & - & $\begin{array}{l}0.54^{* * *} \\
(0.00)\end{array}$ & $\begin{array}{l}0.54^{* * * *} \\
(0.00)\end{array}$ & - & - \\
\hline LN_TA & $\begin{array}{c}-0.28^{*+*_{*}^{*}} \\
(0.00)\end{array}$ & $\begin{array}{l}-0.35^{* * *} \\
(0.00)\end{array}$ & 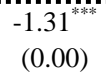 & $\begin{array}{l}-1.62^{\text {*** }} \\
(0.00)\end{array}$ & $\begin{array}{l}-0.73^{* * *} \\
(0.00)\end{array}$ & $\begin{array}{l}-0.74^{* w_{*}^{*}} \\
(0.00)\end{array}$ & $\begin{array}{l}-1.37^{*} \\
(0.00)\end{array}$ & $\begin{array}{c}-1.57^{*} \\
(0.00)\end{array}$ \\
\hline $\mathrm{ROA}$ & $\begin{array}{l}0.64^{* * * *} \\
(0.01)\end{array}$ & $\begin{array}{l}0.67^{\text {*** }} \\
(0.00)\end{array}$ & $\begin{array}{c}0.14 \\
(0.65)\end{array}$ & $\begin{array}{c}0.13 \\
(0.71)\end{array}$ & $\begin{array}{l}0.69^{* *} \\
(0.01)\end{array}$ & $\begin{array}{l}0.72^{* *} \\
(0.01)\end{array}$ & $\begin{array}{c}0.02 \\
(0.94)\end{array}$ & $\begin{array}{c}0.02 \\
(0.92)\end{array}$ \\
\hline LLP & $\begin{array}{c}0.06 \\
(0.16)\end{array}$ & $\begin{array}{c}0.07 \\
(0.14)\end{array}$ & $\begin{array}{l}-0.06 \\
(0.61)\end{array}$ & $\begin{array}{l}-0.10 \\
(0.48)\end{array}$ & $\begin{array}{l}-0.09 \\
(0.22)\end{array}$ & $\begin{array}{l}-0.09 \\
(0.23)\end{array}$ & $\begin{array}{c}0.04 \\
(0.82)\end{array}$ & $\begin{array}{c}0.03 \\
(0.88)\end{array}$ \\
\hline COST_EQ & $\begin{array}{c}-0.44^{* * * *} \\
(0.00)\end{array}$ & $\begin{array}{c}-0.47^{* * *} \\
(0.00)\end{array}$ & $\begin{array}{l}-0.22^{* *} \\
(0.04)\end{array}$ & $\begin{array}{l}-0.24^{* *} \\
(0.04)\end{array}$ & $\begin{array}{l}-0.12 \\
(0.59)\end{array}$ & $\begin{array}{l}-0.12 \\
(0.56)\end{array}$ & $\begin{array}{c}0.01 \\
(0.94)\end{array}$ & $\begin{array}{c}0.01 \\
(0.94)\end{array}$ \\
\hline $\mathrm{CV}$ & $\begin{array}{l}0.14^{*} \\
(0.07)\end{array}$ & $\begin{array}{l}0.15^{*} \\
(0.08)\end{array}$ & $\begin{array}{l}0.25^{* *} \\
(0.04)\end{array}$ & $\begin{array}{l}0.25^{*} \\
(0.05)\end{array}$ & $\begin{array}{l}0.21^{*} \\
(0.08)\end{array}$ & $\begin{array}{l}0.22^{*} \\
(0.06)\end{array}$ & $\begin{array}{c}0.10 \\
(0.59)\end{array}$ & $\begin{array}{c}0.16 \\
(0.41)\end{array}$ \\
\hline LO_TA & $\begin{array}{c}0.00 \\
(0.21)\end{array}$ & $\begin{array}{l}0.00 \\
(0.17)\end{array}$ & $\begin{array}{l}-0.01 \\
(0.10)\end{array}$ & $\begin{array}{l}-0.01 \\
(0.14)\end{array}$ & $\begin{array}{l}-0.03^{* *} \\
(0.01)\end{array}$ & $\begin{array}{c}-0.04^{* * *} \\
(0.00)\end{array}$ & $\begin{array}{c}-0.08^{* * * *} \\
(0.00)\end{array}$ & $\begin{array}{c}-0.08^{* * * *} \\
(0.00)\end{array}$ \\
\hline MKT_DISC & $\begin{array}{c}0.00 \\
(0.82)\end{array}$ & $\begin{array}{l}0.00 \\
(0.75)\end{array}$ & $\begin{array}{l}0.01^{*} \\
(0.06)\end{array}$ & $\begin{array}{l}0.01^{* *} \\
(0.03)\end{array}$ & $\begin{array}{l}0.02^{* *} \\
(0.04)\end{array}$ & $\begin{array}{l}0.02^{* *} \\
(0.02)\end{array}$ & $\begin{array}{l}0.02^{* *} \\
(0.03)\end{array}$ & $\begin{array}{l}0.02^{* *} \\
(0.02)\end{array}$ \\
\hline GDPG & $\begin{array}{l}0.05^{*} \\
(0.09)\end{array}$ & $\begin{array}{l}0.06^{*} \\
(0.08)\end{array}$ & $\begin{array}{c}0.02 \\
(0.62)\end{array}$ & $\begin{array}{c}0.04 \\
(0.40)\end{array}$ & $\begin{array}{c}0.01 \\
(0.84)\end{array}$ & $\begin{array}{c}0.00 \\
(0.89)\end{array}$ & $\begin{array}{c}0.03 \\
(0.54)\end{array}$ & $\begin{array}{c}0.06 \\
(0.29)\end{array}$ \\
\hline LO_GR & $\begin{array}{c}-0.01^{\text {***** }} \\
(0.00)\end{array}$ & $\begin{array}{c}-0.01^{* * * *} \\
(0.00)\end{array}$ & $\begin{array}{c}-0.01^{* * * *} \\
(0.00)\end{array}$ & $\begin{array}{c}-0.01^{* * * *} \\
(0.00)\end{array}$ & $\begin{array}{c}-0.02^{* * * *} \\
(0.00)\end{array}$ & $\begin{array}{c}-0.02^{* * * *} \\
(0.00)\end{array}$ & $\begin{array}{c}-0.02^{* * * *} \\
(0.00)\end{array}$ & $\begin{array}{c}-0.02^{* * * *} \\
(0.00)\end{array}$ \\
\hline BASEL2 & $\begin{array}{l}0.35^{*} \\
(0.05)\end{array}$ & $\begin{array}{l}0.39^{* *} \\
(0.04)\end{array}$ & $\begin{array}{l}0.73^{* * * *} \\
(0.00)\end{array}$ & $\begin{array}{l}0.67^{\text {** }} \\
(0.01)\end{array}$ & $\begin{array}{l}2.17^{* * * *} \\
(0.00)\end{array}$ & $\begin{array}{l}2.14^{\text {**** }} \\
(0.00)\end{array}$ & $\begin{array}{l}3.25^{* * * *} \\
(0.00)\end{array}$ & $\begin{array}{l}3.17^{* * * *} \\
(0.00)\end{array}$ \\
\hline LISTED & $\begin{array}{c}0.25 \\
(0.16)\end{array}$ & $\begin{array}{c}0.32 \\
(0.14)\end{array}$ & $\begin{array}{l}1.54^{* * * *} \\
(0.00)\end{array}$ & $\begin{array}{l}1.92^{* * * *} \\
(0.00)\end{array}$ & $\begin{array}{l}0.99^{*} \\
(0.07)\end{array}$ & $\begin{array}{l}0.98^{*} \\
(0.07)\end{array}$ & $\begin{array}{l}0.89^{*} \\
(0.08)\end{array}$ & $\begin{array}{l}1.05^{*} \\
(0.05)\end{array}$ \\
\hline U_CAP & $\begin{array}{l}-0.77 \\
(0.18)\end{array}$ & - & $\begin{array}{c}-1.88^{* * * *} \\
(0.00)\end{array}$ & - & $\begin{array}{c}0.38 \\
(0.39)\end{array}$ & - & $\begin{array}{c}-1.28^{* * * *} \\
(0.00)\end{array}$ & $\begin{array}{c}-2.47^{* * *} \\
(0.00)\end{array}$ \\
\hline A_CAP & $\begin{array}{l}-0.61 \\
(0.15)\end{array}$ & - & $\begin{array}{c}-1.59^{* * * *} \\
(0.00)\end{array}$ & - & $\begin{array}{l}-0.18 \\
(0.53)\end{array}$ & - & $\begin{array}{c}-1.45^{* * *} \\
(0.00)\end{array}$ & $\begin{array}{c}-1.45^{* * * *} \\
(0.00)\end{array}$ \\
\hline CAP_INDEX & - & $\begin{array}{l}-0.28^{*} \\
(0.05)\end{array}$ & - & $\begin{array}{c}-1.20^{* *} \\
(0.02)\end{array}$ & - & $\begin{array}{c}-1.01^{* * * *} \\
(0.00)\end{array}$ & - & - \\
\hline INTERCEPT & $\begin{array}{l}4.05^{\text {**** }} \\
(0.00)\end{array}$ & $\begin{array}{l}5.56^{* * * *} \\
(0.00)\end{array}$ & $\begin{array}{c}16.82^{* * * *} \\
(0.00)\end{array}$ & $\begin{array}{c}24.91^{* * *} \\
(0.00)\end{array}$ & $\begin{array}{c}10.39^{* * *} \\
(0.00)\end{array}$ & $\begin{array}{c}16.61^{* * * *} \\
(0.00)\end{array}$ & $\begin{array}{c}24.54^{* * * *} \\
(0.00)\end{array}$ & $\begin{array}{c}39.80^{* * *} \\
(0.00)\end{array}$ \\
\hline Observations & 1492 & 1492 & 1557 & 1557 & 1727 & 1727 & 1742 & 1742 \\
\hline Hansen Test & 120.0 & 121.5 & - & - & 168.0 & 170.5 & - & - \\
\hline P-Value & 0.15 & 0.13 & - & - & 0.24 & 0.20 & - & - \\
\hline AR2 Test & 0.27 & 0.08 & - & - & -0.26 & -0.24 & - & - \\
\hline P-Value & 0.78 & 0.93 & - & - & 0.79 & 0.81 & - & - \\
\hline NB of banks & 324 & 324 & 325 & 325 & 350 & 350 & 352 & 352 \\
\hline
\end{tabular}

Table 5 reports the estimation results for the target capital ratio (step 1) for the whole sample of European commercial banks over the 2002-2010 period. In columns Eq.5 and Eq.6, we respectively estimate the target capital ratio using equations 5 $(\mathrm{GMM})$ and 6 (Random Effect Estimator). T1_TA ${ }_{\mathrm{t}-1}$ is the lagged value of T1_TA defined as the ratio of Tier 1 regulatory capital (T1) to total asset (TA). T1_RWA ${ }_{t-1}$ is the lagged value of T1_RWA defined as the ratio of Tier 1 regulatory capital (T1) to risk-weighted asset (RWA). LN_TA is the natural logarithm of bank's total asset. ROA is profitability measured by the return on asset. LLP is the ratio of loan loss provisions to net loans. COST_EQ is the opportunity cost of equity measured by the return on equity. $\mathrm{CV}$ is the bank's charter value measured as the ratio of bank deposits in total deposits of all banks in the country to which the subject bank belongs. LO_TA is the ratio of net loans to total asset. MKT_DISC is the ratio of total long term funding to total funding. GDPG is the real gross domestic product growth. LO_GR is loan growth. BASEL2 is a dummy variable that takes the value one if year is greater than 2006, and zero otherwise. LISTED is a dummy variable equal to one if the bank is listed, and zero otherwise. U_CAP is a dummy variable equal to one if the risk-based Tier 1 capital ratio is less than or equal 4, and zero otherwise. A_CAP is a dummy variable equal to one if the risk-based Tier 1 capital ratio is between 4 and 7, and zero otherwise. CAP_INDEX is a regulatory capital index as defined in table C.1 in Appendix C. Pvalues are shown in parentheses. ${ }^{*} \mathrm{p}<0.1,{ }^{* *} \mathrm{p}<0.05,{ }^{* * *} \mathrm{p}<0.01$. 


\section{Table 6}

Capital adjustment speed and ownership structure for the whole sample over the 20022010 period

\begin{tabular}{|c|c|c|c|c|c|c|c|c|}
\hline \multirow[t]{4}{*}{ Dependent variable } & \multicolumn{8}{|c|}{$\mathrm{ADE}_{\text {it }}$} \\
\hline & \multicolumn{4}{|c|}{$\begin{array}{c}\text { Panel A: active and passive changes } \\
\text { in capital } \\
\end{array}$} & \multicolumn{4}{|c|}{$\begin{array}{l}\text { Panel B: active change in } \\
\text { capital }\end{array}$} \\
\hline & \multicolumn{2}{|c|}{ (1) } & \multicolumn{2}{|c|}{ (2) } & \multicolumn{2}{|c|}{ (1) } & \multicolumn{2}{|c|}{ (2) } \\
\hline & Eq.5 & Eq.6 & Eq.5 & Eq.6 & Eq.5 & Eq.6 & Eq.5 & Eq.6 \\
\hline \multirow[t]{2}{*}{$\mathrm{TDE}_{\mathrm{it}}(\lambda)$} & $0.45^{* * *}$ & $0.43^{* * *}$ & $0.41^{* * *}$ & $0.39^{* * *}$ & $0.43^{* * *}$ & $0.41^{* * *}$ & $0.39^{* * * *}$ & $0.37^{* * *}$ \\
\hline & $(0.00)$ & $(0.00)$ & $(0.00)$ & $(0.00)$ & $(0.00)$ & $(0.00)$ & $(0.00)$ & $(0.00)$ \\
\hline \multirow[t]{2}{*}{$\mathrm{TDE}_{\mathrm{it}} \times \mathrm{BELOW}_{\mathrm{it}-1}(\theta)$} & 0.09 & 0.03 & 0.07 & 0.04 & 0.04 & 0.03 & 0.04 & 0.02 \\
\hline & $(0.46)$ & $(0.81)$ & $(0.14)$ & $(0.21)$ & $(0.77)$ & $(0.60)$ & $(0.59)$ & $(0.65)$ \\
\hline \multirow[t]{2}{*}{$\mathrm{TDE}_{\mathrm{it}} \times \mathrm{W}_{\mathrm{i}} \quad\left(\lambda^{\prime}\right)$} & 0.10 & 0.05 & 0.11 & 0.03 & 0.05 & 0.02 & -0.02 & -0.04 \\
\hline & $(0.31)$ & $(0.57)$ & $(0.10)$ & $(0.26)$ & $(0.66)$ & $(0.42)$ & $(0.73)$ & $(0.51)$ \\
\hline \multirow{2}{*}{$\mathrm{TDE}_{\mathrm{it}} \times \mathrm{BELOW}_{\mathrm{it}-1} \times \mathrm{W}_{\mathrm{i}}\left(\theta^{\prime}\right)$} & $-0.39^{*}$ & $-0.27^{* *}$ & $-0.25^{*}$ & $-0.18^{* * *}$ & $-0.46^{* *}$ & $-0.42^{* * *}$ & $-0.34^{* *}$ & $-0.26^{* * *}$ \\
\hline & $(0.07)$ & $(0.02)$ & $(0.05)$ & $(0.00)$ & $(0.01)$ & $(0.00)$ & $(0.02)$ & $(0.00)$ \\
\hline \multirow[t]{2}{*}{ INTERCEPT } & $0.30^{* * *}$ & 0.13 & $0.42^{* * * *}$ & 0.15 & 0.09 & 0.14 & 0.09 & $-0.15^{* *}$ \\
\hline & $(0.00)$ & $(0.36)$ & $(0.00)$ & $(0.20)$ & $(0.15)$ & $(0.10)$ & $(0.28)$ & $(0.01)$ \\
\hline Number of observations & 1492 & 1492 & 1476 & 1485 & 1489 & 1485 & 1473 & 1479 \\
\hline$\lambda+\theta$ & 0.54 & 0.46 & 0.48 & 0.43 & 0.47 & 0.44 & 0.43 & 0.39 \\
\hline Risk level to reject $\lambda+\theta=0$ & 0.00 & 0.00 & 0.00 & 0.00 & 0.00 & 0.00 & 0.00 & 0.00 \\
\hline$\lambda+\lambda^{\prime}$ & 0.55 & 0.48 & 0.52 & 0.42 & 0.48 & 0.43 & 0.37 & 0.33 \\
\hline Risk level to reject $\lambda+\lambda^{\prime}=0$ & 0.00 & 0.00 & 0.00 & 0.00 & 0.00 & 0.00 & 0.00 & 0.00 \\
\hline$\lambda+\theta+\lambda^{\prime}+\theta^{\prime}$ & 0.25 & 0.24 & 0.34 & 0.28 & 0.06 & 0.04 & 0.07 & 0.09 \\
\hline Risk level to reject $\lambda+\theta+\lambda^{\prime}+\theta^{\prime}=0$ & 0.04 & 0.02 & 0.00 & 0.00 & 0.57 & 0.68 & 0.49 & 0.17 \\
\hline
\end{tabular}

Table 6 reports the estimation results for equation (4) using fixed effect estimator for the whole sample of European Commercial banks over the 2002-2010 period. $\mathrm{ADE}_{\mathrm{it}}=\frac{\mathrm{K}_{\mathrm{it}}}{\mathrm{A}_{\mathrm{it}}}-\frac{\widetilde{\mathrm{K}}_{\mathrm{it}-1}}{\mathrm{~A}_{\mathrm{it}}}$, is the actual deviation. $\mathrm{TDE}_{\mathrm{it}}=\left(\frac{\mathrm{K}_{\mathrm{it}}}{\mathrm{A}_{\mathrm{it}}}\right)^{*}-\frac{\widetilde{\mathrm{K}}_{\mathrm{it}-1}}{\mathrm{~A}_{\mathrm{it}}}$, is the target deviation. $\widetilde{\mathrm{K}}_{\mathrm{it}-1}$, is defined as the lagged value of Tier 1 regulatory capital in panel A and as the sum of the lagged value of Tier 1 regulatory capital and the current net income minus the current dividend payment in panel B. $\left(\frac{K_{\mathrm{it}}}{\mathrm{A}_{\mathrm{it}}}\right)^{*}$ is the target capital ratio defined respectively as the non-weighted Tier 1 capital ratio (T1_TA) and risk-based Tier 1 capital ratio (T1_RWA) in columns (1) and (2). In columns Eq.5 and Eq.6, we respectively estimate the target capital ratio using equations $5(\mathrm{GMM})$ and 6 (Random Effect Estimator). BELOW $\mathrm{it}_{-1}$ is a dummy variable equal to one if the bank capital ratio is below the target at $t-1$, and zero otherwise. $W_{i}$ is a dummy variable equal to one if there is a gap between voting and cash-flow rights of the ultimate shareholder, and zero otherwise. P-values are shown in parentheses. $\mathrm{p}<0.1,{ }^{* *} \mathrm{p}<0.05$, *** $\mathrm{p}<0.01$ 


\section{Table 7.1}

Capital adjustment speed and ownership structure over the 2002-2010 period for banks controlled by a family or a state

\begin{tabular}{|c|c|c|c|c|c|c|c|c|}
\hline \multirow[t]{4}{*}{ Dependent variable } & \multicolumn{8}{|c|}{$\mathrm{ADE}_{\mathrm{it}}$} \\
\hline & \multicolumn{4}{|c|}{$\begin{array}{l}\text { Panel A: active and passive changes } \\
\text { in capital }\end{array}$} & \multicolumn{4}{|c|}{$\begin{array}{l}\text { Panel B: active change in } \\
\text { capital }\end{array}$} \\
\hline & \multicolumn{2}{|c|}{ (1) } & \multicolumn{2}{|c|}{ (2) } & \multicolumn{2}{|c|}{ (1) } & \multicolumn{2}{|c|}{ (2) } \\
\hline & Eq.5 & Eq.6 & Eq.5 & Eq.6 & Eq.5 & Eq.6 & Eq.5 & Eq.6 \\
\hline \multirow[t]{2}{*}{$\mathrm{TDE}_{\text {it }}(\lambda)$} & $0.49^{* *}$ & $0.47^{* * *}$ & $0.45^{* * *}$ & $0.46^{* * *}$ & $0.42^{* * *}$ & $0.46^{* *}$ & $0.39^{* *}$ & $0.41^{* *}$ \\
\hline & $(0.01)$ & $(0.00)$ & $(0.00)$ & $(0.00)$ & $(0.00)$ & $(0.02)$ & $(0.03)$ & $(0.01)$ \\
\hline \multirow[t]{2}{*}{$\mathrm{TDE}_{\mathrm{it}} \times \mathrm{BELOW}_{\mathrm{it}-1}(\theta)$} & -0.03 & -0.02 & 0.04 & 0.01 & 0.02 & -0.03 & 0.05 & 0.04 \\
\hline & $(0.47)$ & $(0.11)$ & $(0.15)$ & $(0.34)$ & $(0.75)$ & $(0.88)$ & $(0.33)$ & $(0.11)$ \\
\hline \multirow[t]{2}{*}{$\mathrm{TDE}_{\mathrm{it}} \times \mathrm{W}_{\mathrm{i}} \quad\left(\lambda^{\prime}\right)$} & 0.04 & -0.01 & 0.01 & 0.05 & 0.01 & 0.03 & 0.07 & 0.05 \\
\hline & $(0.91)$ & $(0.21)$ & $(0.24)$ & $(0.20)$ & $(0.24)$ & $(0.16)$ & $(0.64)$ & $(0.30)$ \\
\hline \multirow[t]{2}{*}{$\mathrm{TDE}_{\mathrm{it}} \times \mathrm{BELOW}_{\mathrm{it}-1} \times \mathrm{W}_{\mathrm{i}}\left(\theta^{\prime}\right)$} & $-0.21^{*}$ & $-0.19^{*}$ & $-0.24^{*}$ & $-0.20^{* * *}$ & $-0.42^{* *}$ & $-0.44^{* *}$ & $-0.50^{* * *}$ & $-0.49^{* * *}$ \\
\hline & $(0.06)$ & $(0.08)$ & $(0.05)$ & $(0.00)$ & $(0.03)$ & $(0.03)$ & $(0.01)$ & $(0.00)$ \\
\hline \multirow[t]{2}{*}{ INTERCEPT } & $0.52^{* * *}$ & 0.30 & $0.36^{* *}$ & 0.28 & 0.25 & $0.29^{* *}$ & -0.02 & -0.24 \\
\hline & $(0.00)$ & $(0.20)$ & $(0.03)$ & $(0.23)$ & $(0.10)$ & $(0.04)$ & $(0.91)$ & $(0.23)$ \\
\hline Number of observations & 428 & 427 & 420 & 418 & 427 & 422 & 420 & 416 \\
\hline$\lambda+\theta$ & 0.46 & 0.45 & 0.49 & 0.47 & 0.44 & 0.43 & 0.44 & 0.45 \\
\hline Risk level to reject $\lambda+\theta=0$ & 0.01 & 0.01 & 0.00 & 0.00 & 0.00 & 0.00 & 0.00 & 0.00 \\
\hline$\lambda+\lambda^{\prime}$ & 0.53 & 0.44 & 0.46 & 0.51 & 0.43 & 0.49 & 0.46 & 0.46 \\
\hline Risk level to reject $\lambda+\lambda^{\prime}=0$ & 0.00 & 0.03 & 0.00 & 0.00 & 0.00 & 0.00 & 0.00 & 0.00 \\
\hline$\lambda+\theta+\lambda^{\prime}+\theta^{\prime}$ & 0.29 & 0.25 & 0.26 & 0.32 & 0.03 & 0.02 & 0.01 & 0.01 \\
\hline Risk level to reject $\lambda+\theta+\lambda^{\prime}+\theta^{\prime}=0$ & 0.02 & 0.08 & 0.03 & 0.00 & 0.87 & 0.48 & 0.89 & 0.78 \\
\hline
\end{tabular}

Table 7.1 reports the estimation results for equation (4) using fixed effect estimator for a subsample of European Commercial banks controlled by a family or a state over the 2002-2010 period. $A D E_{i t}=\frac{K_{i t}}{A_{i t}}-\frac{\widetilde{K}_{i t-1}}{A_{i t}}$, is the actual deviation. $\mathrm{TDE}_{\mathrm{it}}=\left(\frac{\mathrm{K}_{\mathrm{it}}}{\mathrm{A}_{\mathrm{it}}}\right)^{*}-\frac{\widetilde{\mathrm{K}}_{\mathrm{it}-1}}{\mathrm{~A}_{\mathrm{it}}}$, is the target deviation. $\widetilde{\mathrm{K}}_{\mathrm{it}-1}$ is defined as the lagged value of Tier 1 regulatory capital in panel A, and as is the sum of the lagged value of Tier 1 regulatory capital and the current net income minus the current dividend payment in panel B. $\left(\frac{\mathrm{K}_{\mathrm{it}}}{\mathrm{A}_{\mathrm{it}}}\right)^{*}$ is the target capital ratio defined respectively as the non-weighted Tier 1 capital ratio (T1_TA) and risk-based Tier 1 capital ratio (T1_RWA) in columns (1) and (2). In columns Eq.5 and Eq.6, we respectively estimate the target capital ratio using equations 5 (GMM) and 6 (Random Effect Estimator). BELOW $\mathrm{W}_{\mathrm{it}-1}$ is a dummy variable equal to one if the bank capital ratio is below the target at $\mathrm{t}-1$, and zero otherwise. $\mathrm{W}_{\mathrm{i}}$ is a dummy variable equal to one if there is a gap between voting and cash-flow rights of the ultimate shareholder, and zero otherwise. P-values are shown in parentheses. ${ }^{*} \mathrm{p}<0.1,{ }^{* *} \mathrm{p}<0.05,{ }^{* * *} \mathrm{p}<0.01$. 


\section{Table 7.2}

Capital adjustment speed and ownership structure over the 2002-2010 period for banks controlled by other categories than "family" and "state"

\begin{tabular}{|c|c|c|c|c|c|c|c|c|}
\hline \multirow[t]{4}{*}{ Dependent variable } & \multicolumn{8}{|c|}{ ADE $_{\text {it }}$} \\
\hline & \multicolumn{4}{|c|}{$\begin{array}{l}\text { Panel A: active and passive changes } \\
\text { in capital }\end{array}$} & \multicolumn{4}{|c|}{$\begin{array}{c}\text { Panel B: active change in } \\
\text { capital }\end{array}$} \\
\hline & \multicolumn{2}{|c|}{ (1) } & \multicolumn{2}{|c|}{ (2) } & \multicolumn{2}{|c|}{ (1) } & \multicolumn{2}{|c|}{ (2) } \\
\hline & Eq.5 & Eq.6 & Eq.5 & Eq.6 & Eq.5 & Eq.6 & Eq.5 & Eq.6 \\
\hline \multirow[t]{2}{*}{$\mathrm{TDE}_{\mathrm{it}}(\lambda)$} & $0.47^{* * *}$ & $0.42^{* * *}$ & $0.37^{* * *}$ & $0.34^{* * *}$ & $0.50^{* * *}$ & $0.47^{* * *}$ & $0.40^{* * *}$ & $0.34^{* * *}$ \\
\hline & $(0.00)$ & $(0.00)$ & $(0.00)$ & $(0.00)$ & $(0.00)$ & $(0.00)$ & $(0.00)$ & $(0.00)$ \\
\hline \multirow[t]{2}{*}{$\mathrm{TDE}_{\mathrm{it}} \times \mathrm{BELOW}_{\mathrm{it}-1}(\theta)$} & 0.10 & 0.05 & 0.08 & 0.05 & 0.02 & -0.02 & 0.03 & -0.01 \\
\hline & $(0.41)$ & $(0.41)$ & $(0.37)$ & $(0.10)$ & $(0.58)$ & $(0.50)$ & $(0.59)$ & $(0.00)$ \\
\hline \multirow[t]{2}{*}{$\mathrm{TDE}_{\mathrm{it}} \times \mathrm{W}_{\mathrm{i}} \quad\left(\lambda^{\prime}\right)$} & 0.09 & 0.10 & 0.13 & 0.05 & 0.04 & 0.01 & -0.10 & -0.05 \\
\hline & $(0.19)$ & $(0.38)$ & $(0.92)$ & $(0.00)$ & $(0.44)$ & $(0.16)$ & $(0.83)$ & $(0.17)$ \\
\hline \multirow[t]{2}{*}{$\mathrm{TDE}_{\mathrm{it}} \times \mathrm{BELOW}_{\mathrm{it}-1} \times \mathrm{W}_{\mathrm{i}}\left(\theta^{\prime}\right)$} & -0.17 & $-0.30^{*}$ & -0.22 & -0.16 & -0.38 & $-0.36^{*}$ & -0.14 & -0.08 \\
\hline & $(0.74)$ & $(0.08)$ & $(0.26)$ & $(0.00)$ & $(0.52)$ & $(0.09)$ & $(0.50)$ & $(0.19)$ \\
\hline \multirow[t]{2}{*}{ INTERCEPT } & $0.24^{* * * *}$ & 0.10 & $0.43^{* * *}$ & 0.13 & 0.12 & 0.08 & 0.10 & $-0.34^{* * *}$ \\
\hline & $(0.00)$ & $(0.53)$ & $(0.00)$ & $(0.36)$ & $(0.10)$ & $(0.42)$ & $(0.30)$ & $(0.00)$ \\
\hline Number of observations & 1064 & 1056 & 1056 & 1067 & 1062 & 1052 & 1053 & 1063 \\
\hline$\lambda+\theta$ & 0.57 & 0.47 & 0.46 & 0.39 & 0.52 & 0.45 & 0.43 & 0.33 \\
\hline Risk level to reject $\lambda+\theta=0$ & 0.00 & 0.01 & 0.00 & 0.00 & 0.00 & 7.20 & 0.00 & 0.00 \\
\hline$\lambda+\lambda^{\prime}$ & 0.56 & 0.52 & 0.50 & 0.39 & 0.54 & 0.48 & 0.30 & 0.29 \\
\hline Risk level to reject $\lambda+\lambda^{\prime}=0$ & 0.00 & 0.00 & 0.00 & 0.00 & 0.00 & 0.00 & 0.00 & 0.00 \\
\hline$\lambda+\theta+\lambda^{\prime}+\theta^{\prime}$ & 0.30 & 0.27 & 0.36 & 0.28 & 0.18 & 0.10 & 0.19 & 0.20 \\
\hline Risk level to reject $\lambda+\theta+\lambda^{\prime}+\theta^{\prime}=0$ & 0.00 & 0.01 & 0.00 & 0.00 & 0.04 & 0.11 & 0.08 & 0.00 \\
\hline
\end{tabular}

Table 7.2 reports the estimation results for equation (4) using fixed effect estimator for a subsample of European Commercial banks controlled by a bank or another category different from a family or a state over the 2002-2010 period. $\mathrm{ADE}_{\mathrm{it}}=\frac{\mathrm{K}_{\mathrm{it}}}{\mathrm{A}_{\mathrm{it}}}-\frac{\widetilde{\mathrm{K}}_{\mathrm{it}-1}}{\mathrm{~A}_{\mathrm{it}}}$, is the actual deviation. $\mathrm{TDE}_{\mathrm{it}}=\left(\frac{\mathrm{K}_{\mathrm{it}}}{\mathrm{A}_{\mathrm{it}}}\right)^{*}-\frac{\widetilde{\mathrm{K}}_{\mathrm{it}-1}}{\mathrm{~A}_{\mathrm{it}}}$, is the target deviation. $\widetilde{\mathrm{K}}_{\mathrm{it}-1}$ is defined as the lagged value of Tier 1 regulatory capital in panel A, and as is the sum of the lagged value of Tier 1 regulatory capital and the current net income minus the current dividend payment in panel B. $\left(\frac{\mathrm{K}_{\mathrm{it}}}{\mathrm{A}_{\mathrm{it}}}\right)^{*}$ is the target capital ratio defined respectively as the nonweighted Tier 1 capital ratio (T1_TA) and risk-based Tier 1 capital ratio (T1_RWA) in columns (1) and (2). In columns Eq.5 and Eq.6, we respectively estimate the target capital ratio using equations 5 (GMM) and 6 (Random Effect Estimator). BELOW $_{\mathrm{it}-1}$ is a dummy variable equal to one if the capital ratio is below the target at $t-1$, and zero otherwise. $W_{i}$ is a dummy variable equal to one if there is a gap between voting and cash-flow rights of the ultimate shareholder, and zero otherwise. P-values are shown in parentheses. ${ }^{*} \mathrm{p}<0.1,{ }^{* *} \mathrm{p}<0.05,{ }^{* * *} \mathrm{p}<0.01$. 


\section{Table 8.1}

Capital adjustment speed and ownership structure over the 2002-2010 period for banks headquartered in countries with weak shareholder protection

\begin{tabular}{|c|c|c|c|c|c|c|c|c|}
\hline \multirow[t]{4}{*}{ Dependent variable } & \multicolumn{8}{|c|}{$\mathbf{A D E}_{\text {it }}$} \\
\hline & \multicolumn{4}{|c|}{$\begin{array}{c}\text { Panel A: active and passive changes } \\
\text { in capital }\end{array}$} & \multicolumn{4}{|c|}{$\begin{array}{l}\text { Panel B: active change in } \\
\text { capital }\end{array}$} \\
\hline & \multicolumn{2}{|c|}{ (1) } & \multicolumn{2}{|c|}{ (2) } & \multicolumn{2}{|c|}{ (1) } & \multicolumn{2}{|c|}{ (2) } \\
\hline & Eq.5 & Eq.6 & Eq.5 & Eq.6 & Eq.5 & Eq.6 & Eq.5 & Eq.6 \\
\hline \multirow[t]{2}{*}{$\operatorname{TDE}_{\text {it }}(\lambda)$} & $0.43^{* * *}$ & $0.41^{* * * *}$ & $0.39^{* * *}$ & $0.38^{* * *}$ & $0.42^{* * * *}$ & $0.39^{* * *}$ & $0.36^{* * *}$ & $0.35^{\text {*** }}$ \\
\hline & $(0.00)$ & $(0.00)$ & $(0.00)$ & $(0.00)$ & $(0.00)$ & $(0.00)$ & $(0.00)$ & $(0.00)$ \\
\hline \multirow[t]{2}{*}{$\mathrm{TDE}_{\mathrm{it}} \times \mathrm{BELOW}_{\mathrm{it}-1}(\theta)$} & 0.07 & 0.04 & 0.05 & 0.02 & -0.02 & 0.04 & 0.05 & 0.02 \\
\hline & $(0.21)$ & $(0.51)$ & $(0.85)$ & $(0.50)$ & $(0.19)$ & $(0.39)$ & $(0.24)$ & $(0.21)$ \\
\hline \multirow[t]{2}{*}{$\mathrm{TDE}_{\mathrm{it}} \times \mathrm{W}_{\mathrm{i}} \quad\left(\lambda^{\prime}\right)$} & 0.09 & 0.04 & 0.08 & 0.02 & 0.03 & 0.01 & -0.01 & -0.03 \\
\hline & $(0.20)$ & $(0.26)$ & $(0.31)$ & $(0.00)$ & $(0.27)$ & $(0.48)$ & $(0.19)$ & $(0.23)$ \\
\hline \multirow[t]{2}{*}{$\mathrm{TDE}_{\mathrm{it}} \times \mathrm{BELOW}_{\mathrm{it}-1} \times \mathrm{W}_{\mathrm{i}}\left(\theta^{\prime}\right)$} & $-0.38^{* * *}$ & $-0.29^{*}$ & $-0.27^{* *}$ & $-0.18^{* * *}$ & $-0.41^{* *}$ & $-0.43^{* * *}$ & $-0.39^{* * *}$ & $-0.32^{* *}$ \\
\hline & $(0.00)$ & $(0.05)$ & $(0.01)$ & $(0.00)$ & $(0.06)$ & $(0.00)$ & $(0.00)$ & $(0.01)$ \\
\hline \multirow[t]{2}{*}{ INTERCEPT } & $0.51^{* * *}$ & 0.16 & $0.60^{* * *}$ & 0.15 & $0.17^{* *}$ & 0.16 & $0.32^{* * *}$ & $-0.26^{*}$ \\
\hline & $(0.00)$ & $(0.42)$ & $(0.00)$ & $(0.33)$ & $(0.02)$ & $(0.18)$ & $(0.00)$ & $(0.06)$ \\
\hline Number of observations & 1094 & 1076 & 1079 & 1084 & 1092 & 1072 & 1077 & 1082 \\
\hline$\lambda+\theta$ & 0.50 & 0.45 & 0.44 & 0.40 & 0.40 & 0.43 & 0.41 & 0.37 \\
\hline Risk level to reject $\lambda+\theta=0$ & 0.00 & 0.00 & 0.00 & 0.00 & 0.00 & 0.00 & 0.00 & 0.00 \\
\hline$\lambda+\lambda^{\prime}$ & 0.52 & 0.45 & 0.47 & 0.40 & 0.45 & 0.40 & 0.35 & 0.32 \\
\hline Risk level to reject $\lambda+\lambda^{\prime}=0$ & 0.00 & 8.68 & 4.57 & 4.00 & 0.00 & 0.00 & 0.00 & 0.00 \\
\hline$\lambda+\theta+\lambda^{\prime}+\theta^{\prime}$ & 0.21 & 0.20 & 0.25 & 0.24 & 0.02 & 0.01 & 0.01 & 0.02 \\
\hline Risk level to reject $\lambda+\theta+\lambda^{\prime}+\theta^{\prime}=0$ & 0.01 & 0.01 & 0.00 & 0.00 & 0.46 & 0.65 & 0.71 & 0.39 \\
\hline
\end{tabular}

Table 8.1 reports the estimation results for equation (4) using fixed effect estimator for a subsample of European Commercial banks headquartered in countries with weak shareholder protection (the shareholder index is less than the median value) over the 2002-2010 period. $\mathrm{ADE}_{\mathrm{it}}=\frac{\mathrm{K}_{\mathrm{it}}}{\mathrm{A}_{\mathrm{it}}}-\frac{\widetilde{K}_{\mathrm{it}-1}}{\mathrm{~A}_{\mathrm{it}}}$, is the actual deviation. $\mathrm{TDE}_{\mathrm{it}}=\left(\frac{\mathrm{K}_{\mathrm{it}}}{\mathrm{A}_{\mathrm{it}}}\right)^{*}-\frac{\widetilde{\mathrm{K}}_{\mathrm{it}-1}}{\mathrm{~A}_{\mathrm{it}}}$, is the target deviation. $\widetilde{\mathrm{K}}_{\mathrm{it}-1}$ is defined as the lagged value of Tier 1 regulatory capital in panel A, and as is the sum of the lagged value of Tier 1 regulatory capital and the current net income minus the current dividend payment in panel B. $\left(\frac{K_{i t}}{A_{i t}}\right)^{*}$ is the target capital ratio defined respectively as the non-weighted Tier 1 capital ratio (T1_TA) and risk-based Tier 1 capital ratio (T1_RWA) in columns (1) and (2). In columns Eq.5 and Eq.6, we respectively estimate the target capital ratio using equations 5 (GMM) and 6 (Random Effect Estimator). BELOW $\mathrm{W}_{\mathrm{it}-1}$ is a dummy variable equal to one if the bank capital ratio is below the target at $\mathrm{t}-1$, and zero otherwise. $\mathrm{W}_{\mathrm{i}}$ is a dummy variable equal to one if there is a gap between voting and cash-flow rights of the ultimate shareholder, and zero otherwise. P-values are shown in parentheses. ${ }^{*} \mathrm{p}<0.1,{ }^{* *} \mathrm{p}<0.05,{ }^{* * *} \mathrm{p}<0.01$. 


\section{Table 8.2}

Capital adjustment speed and ownership structure over the 2002-2010 period for banks headquartered in countries with strong shareholder protection

\begin{tabular}{|c|c|c|c|c|c|c|c|c|}
\hline \multirow[t]{4}{*}{ Dependent variable } & \multicolumn{8}{|c|}{$\mathbf{A D E}_{\mathrm{it}}$} \\
\hline & \multicolumn{4}{|c|}{$\begin{array}{l}\text { Panel A: active and passive } \\
\text { changes in capital }\end{array}$} & \multicolumn{4}{|c|}{$\begin{array}{c}\text { Panel B: active change in } \\
\text { capital }\end{array}$} \\
\hline & \multicolumn{2}{|c|}{ (1) } & \multicolumn{2}{|c|}{ (2) } & \multicolumn{2}{|c|}{ (1) } & \multicolumn{2}{|c|}{ (2) } \\
\hline & Eq.5 & Eq.6 & Eq.5 & Eq.6 & Eq.5 & Eq.6 & Eq.5 & Eq.6 \\
\hline \multirow[t]{2}{*}{$\mathrm{TDE}_{\text {it }}(\lambda)$} & $0.46^{* *}$ & $0.44^{* *}$ & $0.42^{* * *}$ & $0.40^{* * *}$ & $0.44^{* * *}$ & $0.42^{* * *}$ & $0.40^{*}$ & $0.38^{* * *}$ \\
\hline & $(0.02)$ & $(0.01)$ & $(0.00)$ & $(0.00)$ & $(0.00)$ & $(0.00)$ & $(0.05)$ & $(0.00)$ \\
\hline \multirow[t]{2}{*}{$\mathrm{TDE}_{\mathrm{it}} \times \mathrm{BELOW}_{\mathrm{it}-1}(\theta)$} & 0.11 & 0.04 & 0.09 & 0.06 & 0.08 & 0.03 & 0.05 & 0.02 \\
\hline & $(0.22)$ & $(0.63)$ & $(0.11)$ & $(0.41)$ & $(0.13)$ & $(0.76)$ & $(0.67)$ & $(0.32)$ \\
\hline \multirow[t]{2}{*}{$\mathrm{TDE}_{\mathrm{it}} \times \mathrm{W}_{\mathrm{i}}$} & 0.12 & 0.08 & 0.13 & 0.04 & 0.06 & 0.05 & -0.01 & -0.03 \\
\hline & $(0.31)$ & $(0.84)$ & $(0.87)$ & $(0.36)$ & $(0.21)$ & $(0.13)$ & $(0.95)$ & $(0.25)$ \\
\hline \multirow[t]{2}{*}{$\mathrm{TDE}_{\mathrm{it}} \times \mathrm{BELOW}_{\mathrm{it}-1} \times \mathrm{W}_{\mathrm{i}}\left(\theta^{\prime}\right)$} & -0.39 & -0.24 & -0.28 & $-0.20^{* * *}$ & $-0.38^{* * *}$ & $-0.32^{* *}$ & $-0.28^{* * *}$ & $-0.17^{* * *}$ \\
\hline & $(0.87)$ & $(0.33)$ & $(0.45)$ & $(0.00)$ & $(0.00)$ & $(0.02)$ & $(0.00)$ & $(0.00)$ \\
\hline \multirow[t]{2}{*}{ INTERCEPT } & -0.03 & $0.23^{*}$ & -0.05 & 0.08 & 0.00 & $0.20^{* * *}$ & $-0.47^{* * *}$ & $-0.25^{* *}$ \\
\hline & $(0.70)$ & $(0.07)$ & $(0.74)$ & $(0.51)$ & $(0.93)$ & $(0.04)$ & $(0.00)$ & $(0.02)$ \\
\hline Number of observations & 398 & 404 & 397 & 401 & 397 & 399 & 396 & 397 \\
\hline$\lambda+\theta$ & 0.57 & 0.48 & 0.51 & 0.46 & 0.52 & 0.45 & 0.45 & 0.40 \\
\hline Risk level to reject $\lambda+\theta=0$ & 0.00 & 0.00 & 0.00 & 0.00 & 0.00 & 0.00 & 0.00 & 0.00 \\
\hline$\lambda+\lambda^{\prime}$ & 0.58 & 0.52 & 0.55 & 0.44 & 0.50 & 0.47 & 0.39 & 0.35 \\
\hline Risk level to reject $\lambda+\lambda^{\prime}=0$ & 0.00 & 0.00 & 0.00 & 0.00 & 0.00 & 0.00 & 0.00 & 0.00 \\
\hline$\lambda+\theta+\lambda^{\prime}+\theta^{\prime}$ & 0.30 & 0.32 & 0.36 & 0.32 & 0.20 & 0.18 & 0.16 & 0.20 \\
\hline Risk level to reject $\lambda+\theta+\lambda^{\prime}+\theta^{\prime}=0$ & 0.00 & 0.00 & 0.00 & 0.00 & 0.00 & 0.01 & 0.03 & 0.00 \\
\hline
\end{tabular}

Table 8.2 reports the estimation results for equation (4) using fixed effect estimator for a subsample of European Commercial banks headquartered in countries with strong shareholder protection (the shareholder index is greater than or equal to the median value) over the 2002-2010 period. $\mathrm{ADE}_{\mathrm{it}}=\frac{\mathrm{K}_{\mathrm{it}}}{\mathrm{A}_{\mathrm{it}}}-\frac{\widetilde{\mathrm{K}}_{\mathrm{it}-1}}{\mathrm{~A}_{\mathrm{it}}}$, is the actual deviation. $\mathrm{TDE}_{\mathrm{it}}=\left(\frac{\mathrm{K}_{\mathrm{it}}}{\mathrm{A}_{\mathrm{it}}}\right)^{*}-\frac{\widetilde{\mathrm{K}}_{\mathrm{it}-1}}{\mathrm{~A}_{\mathrm{it}}}$, is the target deviation. $\widetilde{K}_{\mathrm{it}-1}$ is defined as the lagged value of Tier 1 regulatory capital in panel A, and as is the sum of the lagged value of Tier 1 regulatory capital and the current net income minus the current dividend payment in panel B. $\left(\frac{K_{i t}}{A_{i t}}\right)^{*}$ is the target capital ratio defined respectively as the non-weighted Tier 1 capital ratio (T1_TA) and risk-based Tier 1 capital ratio (T1_RWA) in columns (1) and (2). In columns Eq.5 and Eq.6, we respectively estimate the target capital ratio using equations 5 (GMM) and 6 (Random Effect Estimator). BELOW $\mathrm{it}_{-1}$ is a dummy variable equal to one if the bank capital ratio is below the target at $\mathrm{t}-1$, and zero otherwise. $\mathrm{W}_{\mathrm{i}}$ is a dummy variable equal to one if there is a gap between voting and cash-flow rights of the ultimate shareholder, and zero otherwise. P-values are shown in parentheses. ${ }^{*} \mathrm{p}<0.1,{ }^{* *} \mathrm{p}<0.05,{ }^{* * *} \mathrm{p}<0.01$. 


\section{APPENDIX A}

\section{Examples of control chains}

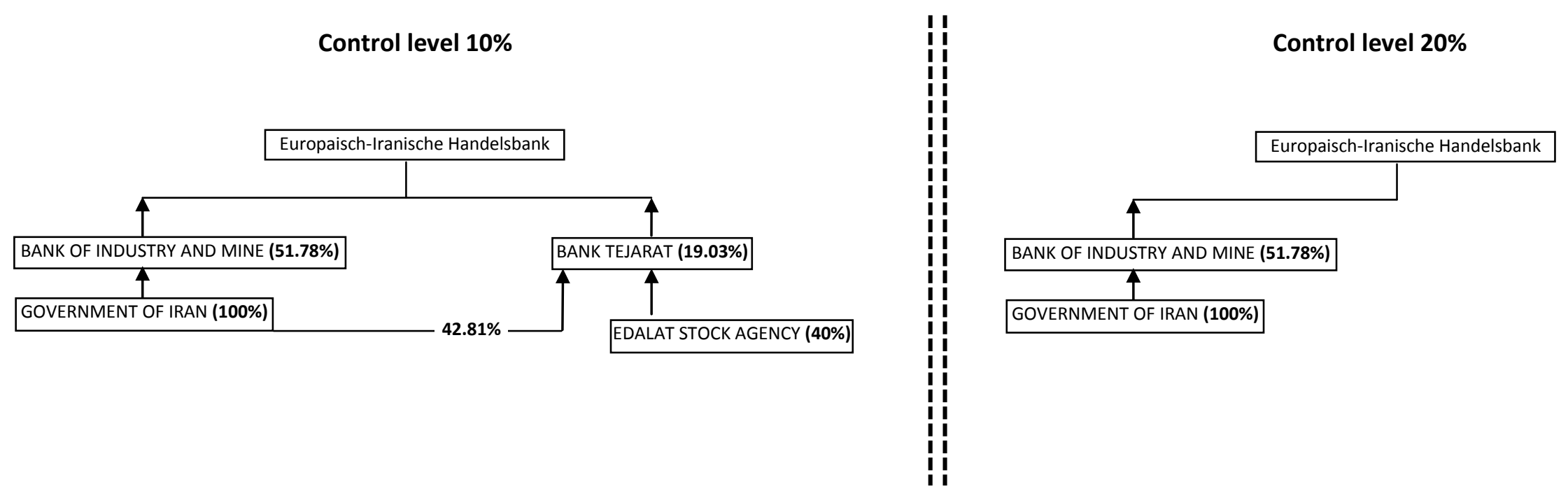

Figure A.1: the control chain of Europaisch-Iranische Handelsbank

The ultimate owner is "GOVERNMENT OF IRAN". It is a multiple holding because UO controls the bank through "BANK OF INDUSTRY AND MINE" and "BANK TEJARAT". $\mathrm{VR}=51.78+19.03=70.81$

$\mathrm{CFR}=100 \% * 51.78 \%+42.81 \% * 19.03 \%=59.92 \%$

WEDGE $=70.81-59.92=10.89 \%$
The ultimate owner is "GOVERNMENT OF IRAN". $\mathrm{VR}=51.78 \%$

$\mathrm{CFR}=100 \% * 51.78 \%=51.78 \%$

WEDGE $=51.78-51.78=0$ 

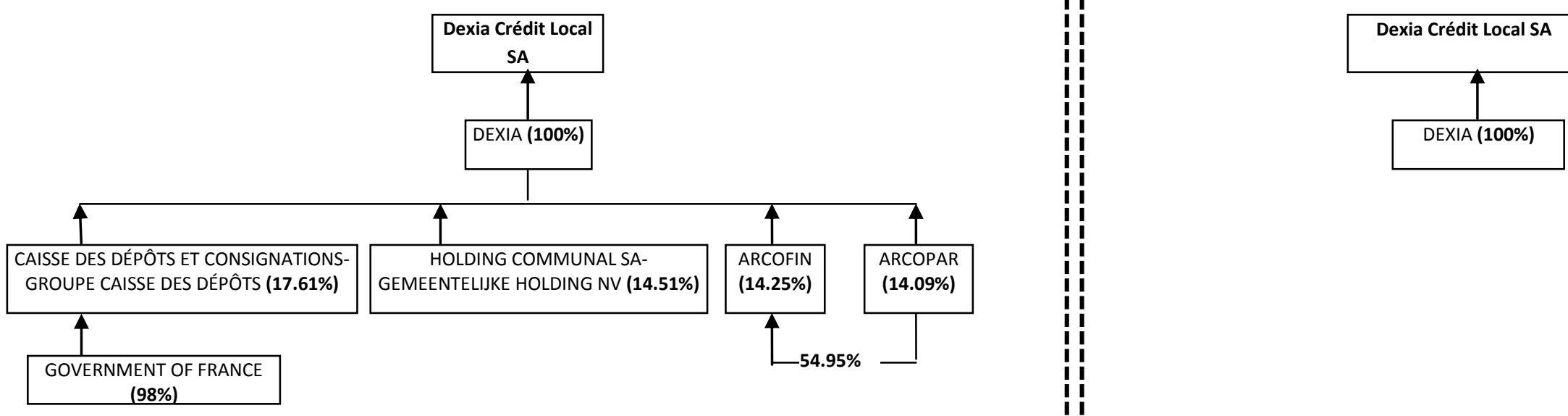

Figure A.2: the control chain of Dexia Crédit Local SA bank

The ultimate owner is "GOVERNMENT OF FRANCE". It is a pyramid. $\mathrm{VR}=100 \%$

$\mathrm{CFR}=100 \% * 17.61 \% * 98 \%=17.25 \%$

WEDGE $=100 \%-17.25 \%=82.75 \%$

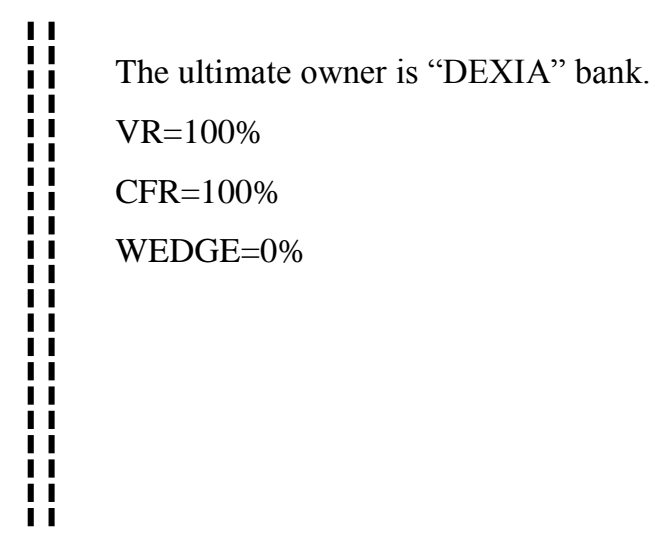




\section{Control level $10 \%$}

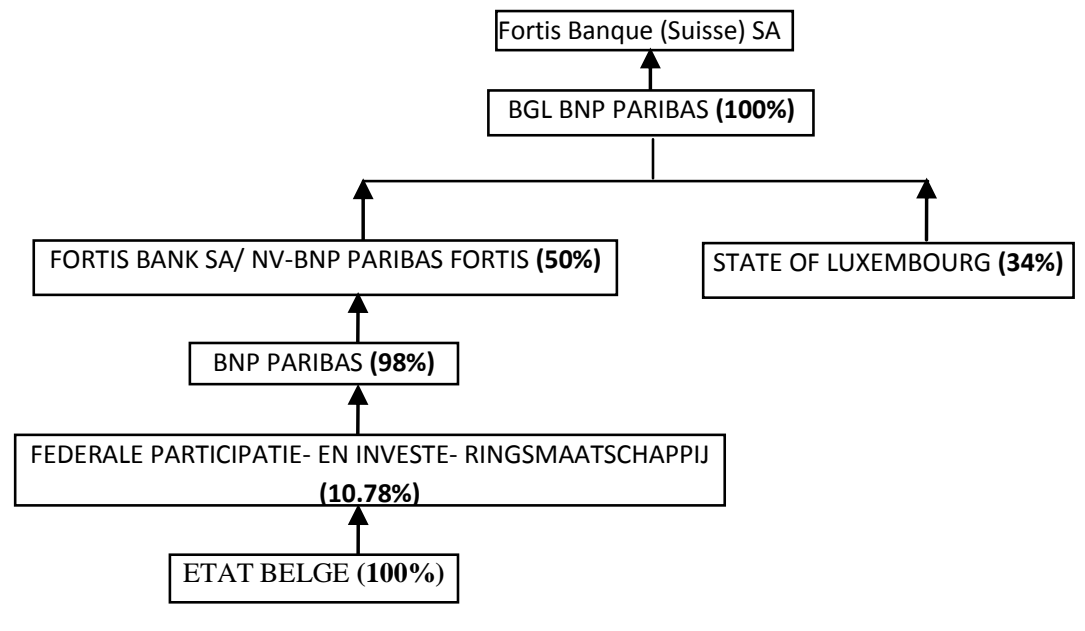

\section{Control level 20\%}

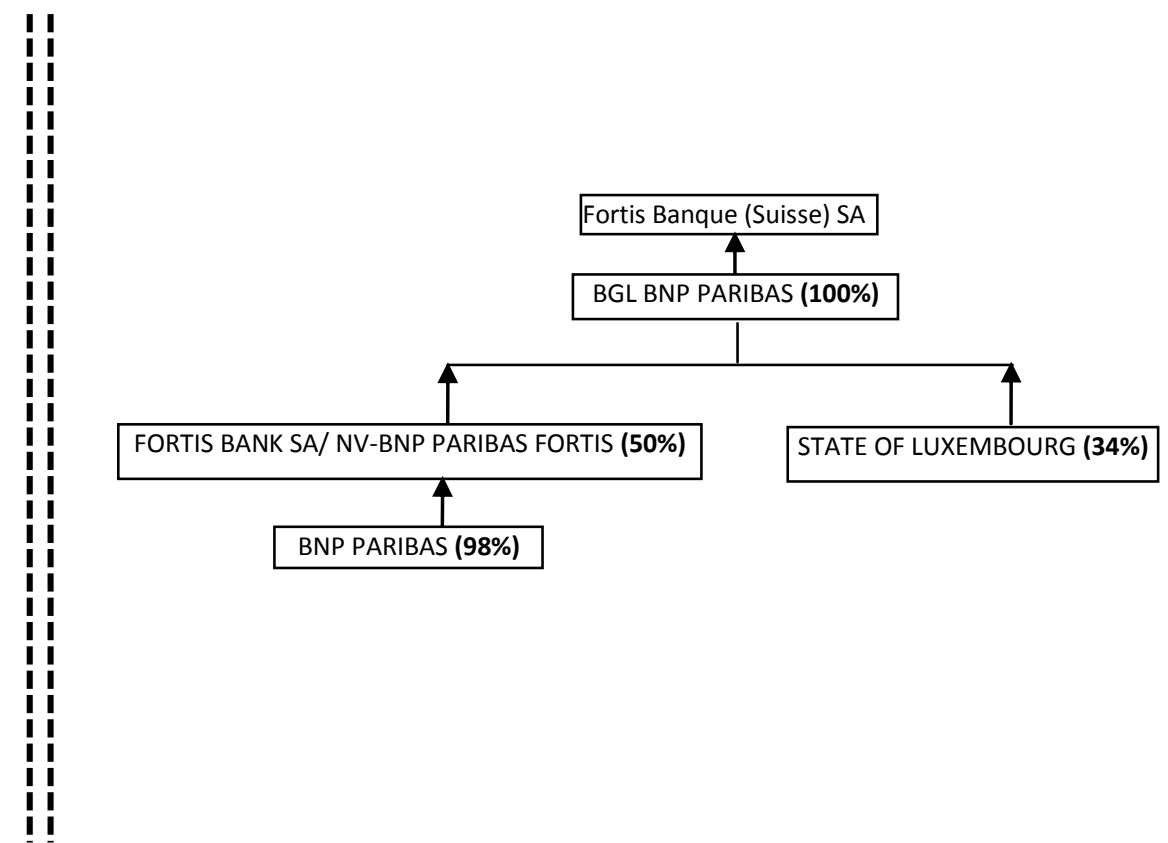

Figure A.3: the control chain of Fortis Banque (Suisse) SA bank

The ultimate owner is "ETAT BELGE". It is a pyramid.

$\mathrm{VR}=100 \%$

$\mathrm{CFR}=100 \% * 50 \% * 98 \% * 10.78 \% * 100 \%=5.28 \%$

WEDGE $=100 \%-5.28 \%=94.72 \%$
The ultimate owner is "BNP PARIBAS" bank. It is a pyramid.

$\mathrm{VR}=100 \%$

$\mathrm{CFR}=100 \% * 50 \% * 98 \%=49 \%$

$\mathrm{WEDGE}=100 \%-49 \%=51 \%$ 
Control level $10 \%$

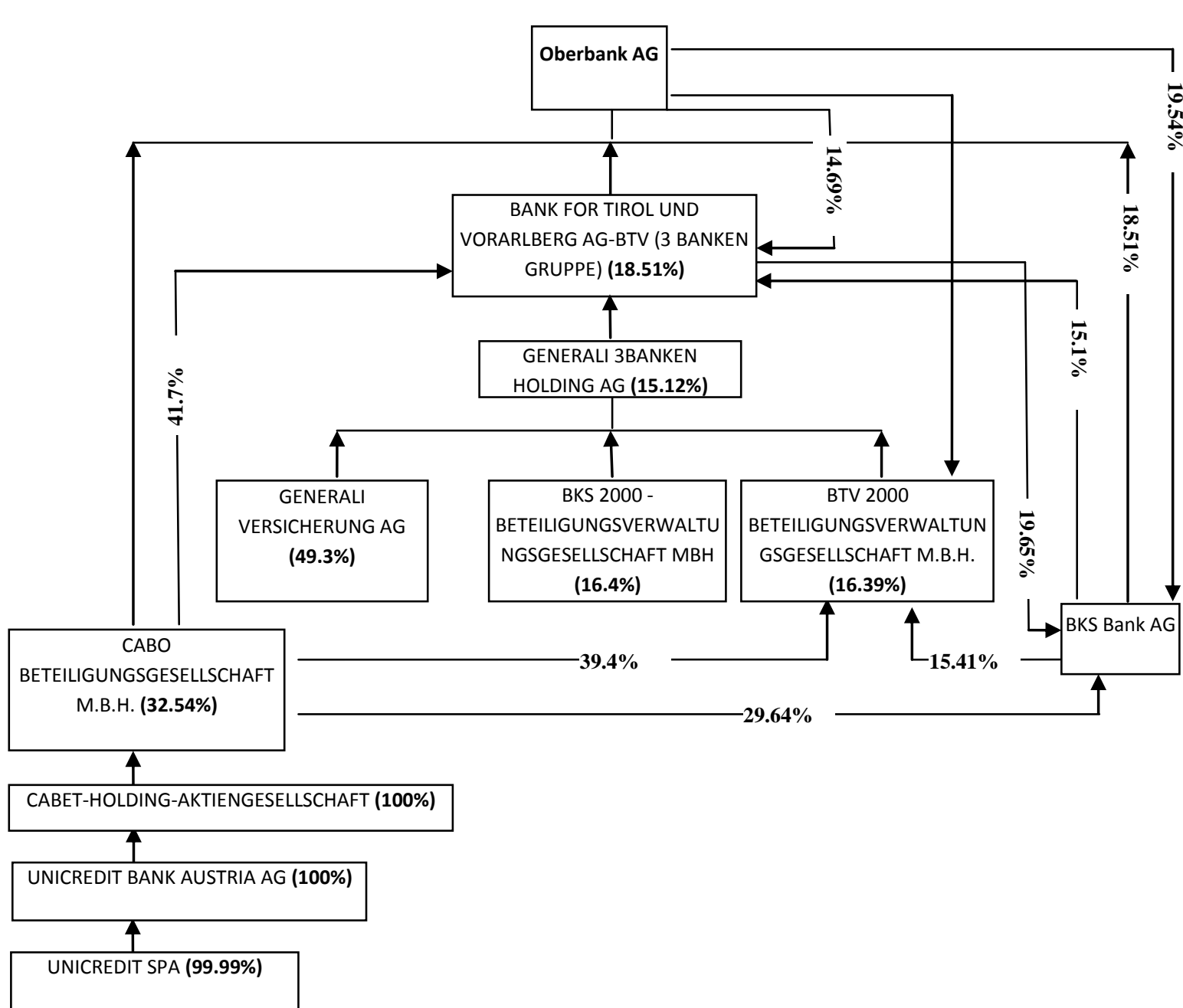

Figure A.4: the control chain of OBERBANK AG bank
It is a cross-holding.

$\mathrm{V}=0$

$\mathrm{CFR}=0$

WEDGE $=0$

\section{Control level $20 \%$}

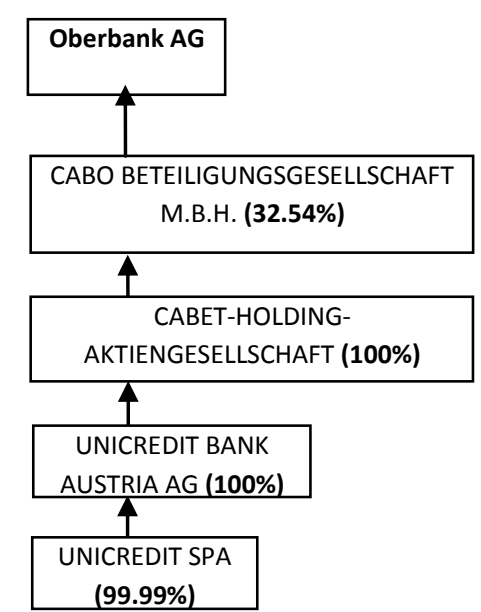

I The ultimate owner is "UNICREDIT SPA" bank. It is a pyramid.

$\mathrm{VR}=32.54 \%$

$\mathrm{CFR}=32.54 \% * 100 \% * 100 \% * 99.99 \%=32.53 \%$

WEDGE $=32.54 \%-32.53 \%=1 \%$ 


\section{APPENDIX B}

$\underline{\text { Table B.1 }}$

Expected signs and magnitudes of capital adjustment speeds

$\mathrm{ADE}_{\mathrm{it}}=\left(\lambda+\theta \mathrm{BELOW}_{\mathrm{it}-1}+\lambda^{\prime} \mathrm{W}_{\mathrm{i}}+\theta^{\prime} \mathrm{BELOW}_{\mathrm{it}-1} \mathrm{~W}_{\mathrm{i}}\right) \mathrm{TDE}_{\mathrm{it}}+\epsilon_{\mathrm{it}}$

\begin{tabular}{|c|c|c|}
\hline & $\begin{array}{c}\text { Downward adjustment } \\
\text { BELOW }_{\text {it-1 }}=0\end{array}$ & Upward adjustment \\
\hline $\mathrm{W}_{\mathrm{i}}=0$ & $\begin{array}{l}0<\lambda<1 \\
\lambda \text { significant }\end{array}$ & $\begin{array}{l}\lambda+\theta \text { positive and significant } \\
\theta \text { positive and non-significant }\end{array}$ \\
\hline $\mathrm{W}_{\mathrm{i}}=1$ & $\begin{array}{l}\lambda+\lambda^{\prime} \text { positive and significant } \\
\lambda^{\prime} \text { non-significant }\end{array}$ & $\begin{array}{l}\theta^{\prime} \text { negative and significant } \\
\text { Extreme case: } \lambda+\theta+\lambda^{\prime}+\theta^{\prime} \text { is non-significant }\end{array}$ \\
\hline
\end{tabular}




\section{APPENDIX C}

$\underline{\text { Table C.1 }}$

\section{Description of the variables used to estimate the target capital ratio}

\begin{tabular}{|c|c|c|c|c|}
\hline Variable & Description & Source & $\begin{array}{l}\text { Expected } \\
\text { sign }\end{array}$ & Authors \\
\hline LN_TA & Natural logarithm of total assets & Bankscope & Negative (-) & (Brewer et al., 2008), (Gropp \& Heider, 2011) \\
\hline ROA & Net income to total asset ratio & Bankscope & Ambiguous (+/-) & $\begin{array}{l}\text { (Flannery \& Rangan, 2008), (Marcus, 1983), (Ayuso } \\
\text { et al., 2004), (Gropp \& Heider, 2011) }\end{array}$ \\
\hline LLP & Loan loss provisions to net loans ratio & Bankscope & Ambiguous (+/-) & $\begin{array}{l}\text { (Ayuso et al., 2004), (Nier \& Baumann, 2006), (Gropp } \\
\& \text { Heider, 2011). }\end{array}$ \\
\hline COST_EQ & Net income to equity ratio & Bankscope & Ambiguous (+/-) & $\begin{array}{l}\text { (Ayuso et al., 2004), (Berger et al., 1995), (Nier \& } \\
\text { Baumann, 2006) }\end{array}$ \\
\hline $\mathrm{CV}$ & $\begin{array}{l}\text { Charter value defined as the ratio of bank deposits in total deposits of all } \\
\text { banks in a given country }\end{array}$ & Bankscope & Ambiguous (+/-) & $\begin{array}{l}\text { (Fonseca \& González, 2010), (Gropp \& Heider, 2011), } \\
\text { (Berger et al., 2008) }\end{array}$ \\
\hline LO_TA & Net loans to total asset ratio & Bankscope & Negative (-) & (Ayuso et al., 2004) \\
\hline MKT_DISC & $\begin{array}{l}\text { Market discipline variable defined as total long term market funding to } \\
\text { total funding ratio }\end{array}$ & Bankscope & Positive (+) & (Nier \& Baumann, 2006) \\
\hline GDPG & Real Growth Domestic Product & World bank database & Ambiguous (+/-) & $\begin{array}{l}\text { (Ayuso et al., 2004), (Jokipii \& Milne, 2008), (Nier \& } \\
\text { Baumann, 2006), (Berger et al., 1995) }\end{array}$ \\
\hline LO_GR & Loan growth & Bankscope & Ambiguous (+/-) & (Shehzad et al., 2010) \\
\hline BASEL2 & Dummy equal to one if year is greater than 2006 , and 0 otherwise & Author's definition & Positive (+) & Authors' calculation \\
\hline
\end{tabular}


Table C.1 (Continued)

\begin{tabular}{|c|c|c|c|c|}
\hline LISTED & Dummy equal to one if the bank is listed, and 0 otherwise & Bankscope & Ambiguous (+/-) & (Shehzad et al., 2010) \\
\hline U_CAP & $\begin{array}{l}\text { Dummy equal to one if Tier } 1 \text { risk based capital ratio is lower or equal to } \\
4 \% \text {, and } 0 \text { otherwise }\end{array}$ & Bankscope & Negative (-) & $\begin{array}{l}\text { (Rime, 2001), (Jokipii \& Milne, 2011), (Jacques \& } \\
\text { Nigro, 1997) }\end{array}$ \\
\hline A_CAP & $\begin{array}{l}\text { Dummy equal to one if Tier } 1 \text { risk based capital ratio is between } 4 \text { and } \\
7 \% \text {, and } 0 \text { otherwise }\end{array}$ & Bankscope & Negative (-) & $\begin{array}{l}\text { (Rime, 2001), (Jokipii \& Milne, 2011), (Jacques \& } \\
\text { Nigro, 1997) }\end{array}$ \\
\hline CAP_INDEX & $\begin{array}{l}\text { Capital index which is the total number of affirmative answers to eleven } \\
\text { questions }{ }^{17}\end{array}$ & $\begin{array}{l}\text { (Barth et al., 2004) } \\
\text { database }\end{array}$ & Positive (+) & (Shehzad et al., 2010), (Laeven \& Levine, 2009) \\
\hline
\end{tabular}

\footnotetext{
${ }^{17}$ Q1: Is the minimum capital ratio in line with the Basel guidelines? Q2: Does the minimum capital ratio vary as a function of market risk? Q3: Does the minimum capital ratio vary as a function of credit risk? Q4: Does the minimum capital ratio vary as a function of operational risk? Q5: Is there a simple leverage ratio that is required? Q6: Is market value of loan losses not realized in accounting books deducted from the book value of capital before minimum capital adequacy is determined? Q7: Are unrealized losses in securities portfolios deducted from the book value of capital before minimum capital adequacy is determined? Q8: Are unrealized foreign exchange losses deducted from the book value of capital before minimum capital adequacy is determined? Q9: Are accounting practices for banks in accordance with International Accounting Standards (IAS)? Q10: Is subordinated debt allowed as part of regulatory capital? Q11: Is subordinated debt required as part of regulatory capital?
} 


\section{APPENDIX D}

$\underline{\text { Table D.1 }}$

Correlation matrix of the main explanatory variables used to estimate the target capital ratio

\begin{tabular}{|c|c|c|c|c|c|c|c|c|c|c|c|c|c|c|}
\hline & LN_TA & LO_TA & ROA & COST_EQ & LLP & MKT_DISC & LO_GR & $\mathrm{CV}$ & GDPG & BASEL2 & LISTED & U_CAP & A_CAP & CAP_INDEX \\
\hline LN_TA & 1.00 & & & & & & & & & & & & & \\
\hline LO_TA & -0.02 & 1.00 & & & & & & & & & & & & \\
\hline ROA & -0.09 & -0.04 & 1.00 & & & & & & & & & & & \\
\hline COST_EQ & 0.12 & -0.01 & 0.72 & 1.00 & & & & & & & & & & \\
\hline LLP & -0.08 & 0.03 & -0.23 & -0.24 & 1.00 & & & & & & & & & \\
\hline MKT_DISC & 0.13 & 0.23 & -0.06 & -0.01 & -0.03 & 1.00 & & & & & & & & \\
\hline LO_GR & -0.10 & 0.18 & 0.11 & 0.14 & -0.14 & 0.00 & 1.00 & & & & & & & \\
\hline CV & 0.60 & -0.08 & -0.03 & 0.10 & -0.08 & -0.02 & -0.05 & 1.00 & & & & & & \\
\hline GDPG & 0.05 & -0.01 & 0.17 & 0.27 & -0.26 & -0.03 & 0.21 & 0.13 & 1.00 & & & & & \\
\hline BASEL2 & 0.06 & 0.00 & -0.09 & -0.12 & 0.10 & 0.01 & -0.08 & -0.07 & -0.25 & 1.00 & & & & \\
\hline LISTED & 0.27 & 0.12 & 0.05 & 0.09 & 0.04 & -0.04 & 0.02 & 0.25 & 0.09 & -0.08 & 1.00 & & & \\
\hline U_CAP & 0.19 & -0.19 & -0.09 & 0.00 & -0.06 & 0.03 & -0.06 & 0.24 & -0.06 & 0.13 & 0.02 & 1.00 & & \\
\hline A_CAP & 0.18 & 0.21 & -0.05 & 0.00 & 0.01 & 0.07 & -0.04 & 0.04 & -0.06 & 0.10 & 0.06 & -0.27 & 1.00 & \\
\hline CAP_INDEX & 0.15 & -0.11 & -0.00 & 0.01 & 0.00 & -0.03 & -0.06 & 0.01 & 0.00 & 0.05 & -0.09 & 0.07 & 0.05 & 1.00 \\
\hline
\end{tabular}

LN_TA is the natural logarithm of bank's total asset. LO_TA is the ratio of net loans to total asset. ROA is profitability measured by the return on asset. COST_EQ is the opportunity cost of equity measured by the return on equity. LLP is the ratio of loan loss provisions to net loans. MKT_DISC is the ratio of total long term funding to total funding. LO GR is loan growth. CV is the bank's charter value measured as the share of bank deposits in total deposits of all banks in a given country. GDPG is the real Gross domestic product growth. BASEL2 is a dummy variable that takes the value one if year is greater to 2006, and zero otherwise. Listed is a dummy variable equal to one if the bank is listed, and zero otherwise. U_CAP is a dummy variable equal to one if the risk-based Tier 1 capital ratio is less than or equal 4 , and zero otherwise. A_CAP is a dummy variable equal to one if the risk-based Tier 1 capital ratio is between 4 and 7 , and zero otherwise. CAP_INDEX is a regulatory capital index as defined in Table C.1. 


\section{APPEDIX E}

\section{$\underline{\text { Table E.1 }}$}

Loans of European commercial banks and the proportion of total loans of sample banks in total loans of all commercial banks available in Bankscope by country

\begin{tabular}{|c|c|c|c|c|c|}
\hline \multirow{3}{*}{ Country } & \multirow{3}{*}{$\begin{array}{l}\begin{array}{l}\text { Commercial Banks } \\
\text { available in Bankscope }\end{array} \\
\text { Loans }\end{array}$} & \multicolumn{4}{|c|}{ Commercial Banks in the final sample } \\
\hline & & \multicolumn{2}{|c|}{ Banks with wedge } & \multicolumn{2}{|c|}{ Banks without wedge } \\
\hline & & Loans & Per cent $^{\mathrm{a}}$ & Loans & Per cent $^{\mathrm{a}}$ \\
\hline Austria & 131550.80 & 21454.89 & 0.16 & 29040.48 & 0.22 \\
\hline Belgium & 514323.90 & 445577.09 & 0.87 & 63650.83 & 0.12 \\
\hline Denmark & 477270.00 & 394232.14 & 0.83 & 44727.45 & 0.09 \\
\hline Finland & 105520.10 & 83157.88 & 0.79 & 184.27 & 0.00 \\
\hline France & 1649908.00 & 545681.05 & 0.33 & 769708.36 & 0.47 \\
\hline Germany & 1350270.00 & 719554.39 & 0.53 & 209164.20 & 0.15 \\
\hline Greece & 202621.80 & 93066.05 & 0.46 & 102861.95 & 0.51 \\
\hline Ireland & 444870.70 & 1590.48 & 0.00 & 446800.36 & 1.00 \\
\hline Italy & 1900353.00 & 679888.37 & 0.36 & 964233.78 & 0.51 \\
\hline Luxembourg & 159875.90 & 73036.14 & 0.46 & 34944.70 & 0.22 \\
\hline Netherlands & 1347776.00 & 394729.16 & 0.29 & 500981.22 & 0.37 \\
\hline Norway & 181535.50 & 126625.49 & 0.70 & 2923.40 & 0.02 \\
\hline Portugal & 138297.50 & 7963.75 & 0.06 & 107902.20 & 0.78 \\
\hline Spain & 1330837.00 & 274207.22 & 0.21 & 944216.41 & 0.71 \\
\hline Sweeden & 286477.20 & 470.35 & 0.00 & 231430.02 & 0.81 \\
\hline Switzerland & 544670.60 & 11623.94 & 0.02 & 388547.82 & 0.71 \\
\hline United Kingdom & 2900402.00 & 1974273.54 & 0.68 & 428936.23 & 0.15 \\
\hline Total & 13666560.00 & $\mathbf{5 8 4 7 1 3 1 . 9 5}$ & 0.43 & 5270253.66 & 0.39 \\
\hline
\end{tabular}

${ }^{a}$ is the proportion of loans of a commercial bank with or without wedge in total loans of all commercial banks provided in Bankscope in a given country. 


\section{APPENDIX F}

\section{$\underline{\text { Table F.1 }}$}

Capital adjustment speed and ownership structure over the 2002-2010 period for controlled banks

\begin{tabular}{|c|c|c|c|c|c|c|c|c|}
\hline \multirow[t]{4}{*}{$\overline{\text { Dependent variable }}$} & \multicolumn{8}{|c|}{$\mathbf{A D E}_{\mathrm{it}}$} \\
\hline & \multicolumn{4}{|c|}{$\begin{array}{c}\text { Panel A: active and passive changes } \\
\text { in capital }\end{array}$} & \multicolumn{4}{|c|}{$\begin{array}{c}\text { Panel B: active change } \\
\text { in capital }\end{array}$} \\
\hline & \multicolumn{2}{|c|}{ (1) } & \multicolumn{2}{|c|}{ (2) } & \multicolumn{2}{|c|}{ (1) } & \multicolumn{2}{|c|}{ (2) } \\
\hline & $\mathrm{Eq} .5$ & Eq.6 & Eq.5 & Eq.6 & Eq.5 & Eq.6 & Eq.5 & Eq.6 \\
\hline \multirow[t]{2}{*}{$\operatorname{TDE}_{i t}(\lambda)$} & $0.49^{* * *}$ & $0.47^{* * *}$ & $0.40^{* * * *}$ & $0.37^{* * *}$ & $0.46^{* * *}$ & $0.43^{* * *}$ & $0.39^{* * * *}$ & $0.38^{* * *}$ \\
\hline & $(0.00)$ & $(0.00)$ & $(0.00)$ & $(0.00)$ & $(0.00)$ & $(0.00)$ & $(0.00)$ & $(0.00)$ \\
\hline \multirow[t]{2}{*}{$\mathrm{TDE}_{\mathrm{it}} \times \mathrm{BELOW}_{\mathrm{it}-1}(\theta)$} & 0.02 & 0.03 & 0.08 & 0.03 & 0.00 & 0.03 & 0.03 & 0.02 \\
\hline & $(0.90)$ & $(0.82)$ & $(0.37)$ & $(0.00)$ & $(0.97)$ & $(0.65)$ & $(0.75)$ & $(0.74)$ \\
\hline \multirow{2}{*}{$\mathrm{TDE}_{\mathrm{it}} \times \mathrm{W}_{\mathrm{i}} \quad\left(\lambda^{\prime}\right)$} & 0.07 & -0.04 & 0.11 & 0.05 & 0.05 & 0.05 & -0.00 & 0.04 \\
\hline & $(0.57)$ & $(0.68)$ & $(0.12)$ & $(0.00)$ & $(0.69)$ & $(0.56)$ & $(0.91)$ & $(0.47)$ \\
\hline \multirow[t]{2}{*}{$\mathrm{TDE}_{\text {it }} \times \mathrm{BELOW}_{\mathrm{it}-1} \times \mathrm{W}_{\mathrm{i}}\left(\theta^{\prime}\right)$} & -0.37 & -0.17 & -0.31 & $-0.18^{* *}$ & $-0.47^{*}$ & $-0.46^{* * *}$ & $-0.37^{* * *}$ & $-0.36^{* * *}$ \\
\hline & $(0.14)$ & $(0.49)$ & $(0.13)$ & $(0.02)$ & $(0.05)$ & $(0.00)$ & $(0.00)$ & $(0.00)$ \\
\hline \multirow[t]{2}{*}{ INTERCEPT } & $0.35^{* * *}$ & 0.11 & $0.46^{* * *}$ & 0.20 & $0.13^{*}$ & $0.15^{*}$ & 0.13 & $-0.26^{* *}$ \\
\hline & $(0.00)$ & $(0.48)$ & $(0.00)$ & $(0.14)$ & $(0.09)$ & $(0.08)$ & $(0.21)$ & $(0.03)$ \\
\hline Number of observations & 1259 & 1263 & 1243 & 1249 & 1256 & 1254 & 1240 & 1243 \\
\hline$\lambda+\theta$ & 0.51 & 0.50 & 0.48 & 0.40 & 0.47 & 0.46 & 0.42 & 0.40 \\
\hline Risk level to reject $\lambda+\theta=0$ & 0.00 & 0.00 & 0.00 & 0.00 & 0.00 & 0.00 & 0.00 & 0.00 \\
\hline$\lambda+\lambda^{\prime}$ & 0.56 & 0.43 & 0.51 & 0.42 & 0.51 & 0.48 & 0.39 & 0.42 \\
\hline Risk level to reject $\lambda+\lambda^{\prime}=0$ & 0.00 & 0.00 & 0.00 & 0.00 & 0.00 & 0.00 & 0.00 & 0.00 \\
\hline$\lambda+\theta+\lambda^{\prime}+\theta^{\prime}$ & 0.22 & 0.29 & 0.28 & 0.27 & 0.04 & 0.05 & 0.05 & 0.08 \\
\hline Risk level to reject $\lambda+\theta+\lambda^{\prime}+\theta^{\prime}=0$ & 0.06 & 0.00 & 0.00 & 0.00 & 0.70 & 0.19 & 0.58 & 0.75 \\
\hline
\end{tabular}

Table F.1 reports the estimation results for equation (4) using fixed effect estimator for a subsample of European Commercial controlled banks over the 2002-2010 period. $\mathrm{ADE}_{\mathrm{it}}=\frac{\mathrm{K}_{\mathrm{it}}}{\mathrm{A}_{\mathrm{it}}}-\frac{\widetilde{\mathrm{K}}_{\mathrm{it}-1}}{\mathrm{~A}_{\mathrm{it}}}$, is the actual deviation. $\mathrm{TDE}_{\mathrm{it}}=\left(\frac{\mathrm{K}_{\mathrm{it}}}{\mathrm{A}_{\mathrm{it}}}\right)^{*}-\frac{\widetilde{\mathrm{K}}_{\mathrm{it}-1}}{\mathrm{~A}_{\mathrm{it}}}$, is the target deviation. $\widetilde{\mathrm{K}}_{\mathrm{it}-1}$ is defined as the lagged value of Tier 1 regulatory capital in panel A, and as is the sum of the lagged value of Tier 1 regulatory capital and the current net income minus the current dividend payment in panel $\mathrm{B} .\left(\frac{\mathrm{K}_{\mathrm{it}}}{\mathrm{A}_{\mathrm{it}}}\right)^{*}$ is the target capital ratio defined respectively as the non-weighted Tier 1 capital ratio (T1_TA) and risk-based Tier 1 capital ratio (T1_RWA) in columns (1) and (2). In columns Eq.5 and Eq.6, we respectively estimate the target capital ratio using equations 5 (GMM) and 6 (Random Effect Estimator). BELOW $\mathrm{it}_{-1}$ is a dummy variable equal to one if the bank capital ratio is below the target at $\mathrm{t}-1$, and zero otherwise. $\mathrm{W}_{\mathrm{i}}$ is a dummy variable equal to one if there is a gap between voting and cash-flow rights of the ultimate shareholder, and zero otherwise. P-values are shown in parentheses. ${ }^{*} \mathrm{p}<0.1,{ }^{* *} \mathrm{p}<0.05,{ }^{* * *} \mathrm{p}<0.01$. 


\section{Table F.2}

Capital adjustment speed and ownership structure over the 2002-2010 period for listed banks

\begin{tabular}{|c|c|c|c|c|c|c|c|c|}
\hline \multirow[t]{4}{*}{ Dependent variable } & \multicolumn{8}{|c|}{$\mathbf{A D E}_{\mathrm{it}}$} \\
\hline & \multicolumn{4}{|c|}{$\begin{array}{l}\text { Panel A: active and passive changes } \\
\text { in capital }\end{array}$} & \multicolumn{4}{|c|}{$\begin{array}{c}\text { Panel B: active change in } \\
\text { capital }\end{array}$} \\
\hline & \multicolumn{2}{|c|}{ (1) } & \multicolumn{2}{|c|}{ (2) } & \multicolumn{2}{|c|}{ (1) } & \multicolumn{2}{|c|}{ (2) } \\
\hline & Eq.5 & Eq.6 & Eq.5 & Eq.6 & Eq.5 & Eq.6 & Eq.5 & Eq.6 \\
\hline \multirow[t]{2}{*}{$\mathrm{TDE}_{\text {it }}(\lambda)$} & $0.49^{* * *}$ & $0.47^{* * * *}$ & $0.44^{* *}$ & $0.45^{* * *}$ & $0.46^{* * *}$ & $0.45^{* * *}$ & $0.38^{* * *}$ & $0.41^{* * *}$ \\
\hline & $(0.00)$ & $(0.00)$ & $(0.01)$ & $(0.00)$ & $(0.00)$ & $(0.00)$ & $(0.00)$ & $(0.00)$ \\
\hline \multirow[t]{2}{*}{$\mathrm{TDE}_{\mathrm{it}} \times \mathrm{BELOW}_{\mathrm{it}-1}(\theta)$} & -0.03 & -0.04 & 0.05 & 0.05 & 0.04 & -0.01 & 0.06 & 0.02 \\
\hline & $(0.56)$ & $(0.34)$ & $(0.59)$ & $(0.55)$ & $(0.39)$ & $(0.18)$ & $(0.67)$ & $(0.29)$ \\
\hline \multirow[t]{2}{*}{$\mathrm{TDE}_{\mathrm{it}} \times \mathrm{W}_{\mathrm{i}} \quad\left(\lambda^{\prime}\right)$} & 0.04 & 0.02 & 0.02 & 0.05 & -0.01 & -0.02 & 0.04 & 0.02 \\
\hline & $(0.43)$ & $(0.25)$ & $(0.27)$ & $(0.58)$ & $(0.10)$ & $(0.51)$ & $(0.46)$ & $(0.26)$ \\
\hline \multirow{2}{*}{$\mathrm{TDE}_{\mathrm{it}} \times \mathrm{BELOW}_{\mathrm{it}-1} \times \mathrm{W}_{\mathrm{i}}\left(\theta^{\prime}\right)$} & $-0.23^{* *}$ & $-0.19^{*}$ & $-0.16^{* *}$ & $-0.23^{*}$ & $-0.42^{* *}$ & $-0.36^{* *}$ & $-0.40^{* * *}$ & $-0.40^{* *}$ \\
\hline & $(0.04)$ & $(0.07)$ & $(0.02)$ & $(0.05)$ & $(0.03)$ & $(0.01)$ & $(0.00)$ & $(0.01)$ \\
\hline \multirow[t]{2}{*}{ INTERCEPT } & $0.27^{* * *}$ & $0.81^{* * * *}$ & 0.02 & -0.07 & -0.07 & 0.09 & $-0.43^{* * *}$ & $-0.33^{* * *}$ \\
\hline & $(0.00)$ & $(0.00)$ & $(0.96)$ & $(0.55)$ & $(0.30)$ & $(0.20)$ & $(0.00)$ & $(0.00)$ \\
\hline Number of observations & 629 & 635 & 630 & 635 & 629 & 630 & 630 & 631 \\
\hline$\lambda+\theta$ & 0.46 & 0.43 & 0.49 & 0.50 & 0.50 & 0.44 & 0.44 & 0.43 \\
\hline Risk level to reject $\lambda+\theta=0$ & 0.00 & 0.00 & 0.00 & 0.00 & 0.00 & 0.00 & 0.00 & 0.00 \\
\hline$\lambda+\lambda^{\prime}$ & 0.53 & 0.49 & 0.46 & 0.50 & 0.45 & 0.43 & 0.42 & 0.43 \\
\hline Risk level to reject $\lambda+\lambda^{\prime}=0$ & 0.00 & 0.00 & 0.00 & 0.00 & 0.00 & 0.00 & 0.00 & 0.00 \\
\hline$\lambda+\theta+\lambda^{\prime}+\theta^{\prime}$ & 0.27 & 0.26 & 0.30 & 0.32 & 0.07 & 0.06 & 0.08 & 0.05 \\
\hline Risk level to reject $\lambda+\theta+\lambda^{\prime}+\theta^{\prime}=0$ & 0.00 & 0.01 & 0.00 & 0.00 & 0.21 & 0.32 & 0.20 & 0.48 \\
\hline
\end{tabular}

Table F.2 reports the estimation results for equation (4) using fixed effect estimator for a subsample of European Commercial listed banks over the 2002-2010 period. $\mathrm{ADE}_{\mathrm{it}}=\frac{\mathrm{K}_{\mathrm{it}}}{\mathrm{A}_{\mathrm{it}}}-\frac{\widetilde{\mathrm{K}}_{\mathrm{it}-1}}{\mathrm{~A}_{\mathrm{it}}}$, is the actual deviation. $\mathrm{TDE}_{\mathrm{it}}=\left(\frac{\mathrm{K}_{\mathrm{it}}}{\mathrm{A}_{\mathrm{it}}}\right)^{*}-\frac{\widetilde{\mathrm{K}}_{\mathrm{it}-1}}{\mathrm{~A}_{\mathrm{it}}}$, is the target deviation. $\widetilde{\mathrm{K}}_{\mathrm{it}-1}$ is defined as the lagged value of Tier 1 regulatory capital in panel A, and as is the sum of the lagged value of Tier 1 regulatory capital and the current net income minus the current dividend payment in panel B. $\left(\frac{K_{\mathrm{it}}}{\mathrm{A}_{\mathrm{it}}}\right)^{*}$ is the target capital ratio defined respectively as the non-weighted Tier 1 capital ratio (T1_TA) and risk-based Tier 1 capital ratio (T1_RWA) in columns (1) and (2). In columns Eq.5 and Eq.6, we respectively estimate the target capital ratio using equations 5 (GMM) and 6 (Random Effect Estimator). BELOW $\mathrm{it-1}$ is a dummy variable equal to one if the bank capital ratio is below the target at $\mathrm{t}-1$, and zero otherwise. $\mathrm{W}_{\mathrm{i}}$ is a dummy variable equal to one if there is a gap between voting and cash-flow rights of the ultimate shareholder, and zero otherwise. P-values are shown in parentheses. ${ }^{*} \mathrm{p}<0.1,{ }^{* *} \mathrm{p}<0.05,{ }^{* * *} \mathrm{p}<0.01$. 


\section{$\underline{\text { Table F.3 }}$}

\section{Capital adjustment speed and ownership structure over the 2002-2006 period}

\begin{tabular}{|c|c|c|c|c|c|c|c|c|}
\hline \multirow[t]{4}{*}{ Dependent variable } & \multicolumn{8}{|c|}{$\mathbf{A D E}_{\mathrm{it}}$} \\
\hline & \multicolumn{4}{|c|}{$\begin{array}{l}\text { Panel A: active and passive changes } \\
\text { in capital }\end{array}$} & \multicolumn{4}{|c|}{$\begin{array}{l}\text { Panel B: active change in } \\
\text { capital }\end{array}$} \\
\hline & \multicolumn{2}{|c|}{ (1) } & \multicolumn{2}{|c|}{ (2) } & \multicolumn{2}{|c|}{ (1) } & \multicolumn{2}{|c|}{ (2) } \\
\hline & $\mathbf{E q} .5$ & Eq.6 & $\mathrm{Eq} .5$ & Eq.6 & Eq.5 & Eq.6 & Eq.5 & Eq.6 \\
\hline \multirow[t]{2}{*}{$\mathrm{TDE}_{\mathrm{it}}(\lambda)$} & $0.47^{* * *}$ & $0.45^{* * *}$ & $0.39^{* * *}$ & $0.40^{* * *}$ & $0.46^{* * *}$ & $0.45^{* * *}$ & $0.42^{* * *}$ & $0.38^{* * *}$ \\
\hline & $(0.00)$ & $(0.00)$ & $(0.00)$ & $(0.00)$ & $(0.00)$ & $(0.00)$ & $(0.00)$ & $(0.00)$ \\
\hline \multirow[t]{2}{*}{$\mathrm{TDE}_{\mathrm{it}} \times \mathrm{BELOW}_{\mathrm{it}-1}(\theta)$} & -0.02 & -0.04 & -0.03 & -0.03 & 0.05 & 0.03 & 0.02 & 0.04 \\
\hline & $(0.34)$ & $(0.24)$ & $(0.87)$ & $(0.33)$ & $(0.56)$ & $(0.68)$ & $(0.88)$ & $(0.42)$ \\
\hline \multirow[t]{2}{*}{$\mathrm{TDE}_{\mathrm{it}} \times \mathrm{W}_{\mathrm{i}} \quad\left(\lambda^{\prime}\right)$} & 0.06 & 0.05 & 0.04 & 0.03 & 0.00 & 0.03 & 0.03 & 0.04 \\
\hline & $(0.75)$ & $(0.59)$ & $(0.74)$ & $(0.37)$ & $(0.99)$ & $(0.39)$ & $(0.73)$ & $(0.48)$ \\
\hline \multirow[t]{2}{*}{$\mathrm{TDE}_{\mathrm{it}} \times \mathrm{BELOW}_{\mathrm{it}-1} \times \mathrm{W}_{\mathrm{i}}\left(\theta^{\prime}\right)$} & -0.20 & -0.21 & $-0.16^{* *}$ & $-0.13^{*}$ & $-0.45^{* * *}$ & $-0.46^{* * *}$ & $-0.42^{* * *}$ & $-0.43^{* * *}$ \\
\hline & $(0.33)$ & $(0.12)$ & $(0.03)$ & $(0.09)$ & $(0.00)$ & $(0.00)$ & $(0.00)$ & $(0.00)$ \\
\hline \multirow[t]{2}{*}{ INTERCEPT } & $0.55^{* * *}$ & 0.46 & $0.94^{* * *}$ & -0.13 & $0.28^{* *}$ & $0.61^{* * *}$ & $0.52^{* * *}$ & $-0.50^{* * *}$ \\
\hline & $(0.00)$ & $(0.16)$ & $(0.00)$ & $(0.47)$ & $(0.02)$ & $(0.00)$ & $(0.00)$ & $(0.00)$ \\
\hline Number of observations & 620 & 631 & 609 & 623 & 618 & 629 & 608 & 624 \\
\hline$\lambda+\theta$ & 0.45 & 0.41 & 0.36 & 0.37 & 0.51 & 0.48 & 0.44 & 0.42 \\
\hline Risk level to reject $\lambda+\theta=0$ & 0.00 & 0.00 & 0.00 & 0.00 & 0.00 & 0.00 & 0.00 & 0.00 \\
\hline$\lambda+\lambda^{\prime}$ & 0.53 & 0.50 & 0.43 & 0.43 & 0.46 & 0.48 & 0.45 & 0.42 \\
\hline Risk level to reject $\lambda+\lambda^{\prime}=0$ & 0.00 & 0.00 & 0.00 & 0.00 & 0.00 & 0.00 & 0.00 & 4.45 \\
\hline$\lambda+\theta+\lambda^{\prime}+\theta^{\prime}$ & 0.31 & 0.25 & 0.24 & 0.27 & 0.06 & 0.05 & 0.05 & 0.03 \\
\hline Risk level to reject $\lambda+\theta+\lambda^{\prime}+\theta^{\prime}=0$ & 0.00 & 0.00 & 0.01 & 0.00 & 0.45 & 0.79 & 0.36 & 0.55 \\
\hline
\end{tabular}

Table F.3 reports the estimation results for equation (4) using fixed effect estimator for the whole sample of European Commercial over the period 2002-2006. $\mathrm{ADE}_{\mathrm{it}}=\frac{\mathrm{K}_{\mathrm{it}}}{\mathrm{A}_{\mathrm{it}}}-\frac{\widetilde{\mathrm{K}}_{\mathrm{it}-1}}{\mathrm{~A}_{\mathrm{it}}}$, is the actual deviation. $\mathrm{TDE}_{\mathrm{it}}=\left(\frac{\mathrm{K}_{\mathrm{it}}}{\mathrm{A}_{\mathrm{it}}}\right)^{*}-\frac{\widetilde{\mathrm{K}}_{\mathrm{it}-1}}{\mathrm{~A}_{\mathrm{it}}}$, is the target deviation. $\widetilde{\mathrm{K}}_{\mathrm{it}-1}$ is defined as the lagged value of Tier 1 regulatory capital in panel A, and as is the sum of the lagged value of Tier 1 regulatory capital and the current net income minus the current dividend payment in panel B. $\left(\frac{K_{i t}}{A_{\text {it }}}\right)^{*}$ is the target capital ratio defined respectively as the non-weighted Tier 1 capital ratio (T1_TA) and risk-based Tier 1 capital ratio (T1_RWA) in columns (1) and (2). In columns Eq.5 and Eq.6, we respectively estimate the target capital ratio using equations 5 (GMM) and 6 (Random Effect Estimator). BELOW $\mathrm{it-1}$ is a dummy variable equal to one if the bank capital ratio is below the target at $\mathrm{t}-1$, and zero otherwise. $\mathrm{W}_{\mathrm{i}}$ is a dummy variable equal to one if there is a gap between voting and cash-flow rights of the ultimate shareholder, and zero otherwise. P-values are shown in parentheses. ${ }^{*} \mathrm{p}<0.1,{ }^{* *} \mathrm{p}<0.05,{ }^{* * *} \mathrm{p}<0.01$. 


\section{Table F.4}

Capital adjustment speed and ownership structure over the 2002-2010 period for banks above the regulatory capital requirement

\begin{tabular}{|c|c|c|c|c|c|c|c|c|}
\hline \multirow[t]{4}{*}{ Dependent variable } & \multicolumn{8}{|c|}{$\overline{\text { ADE }_{\text {it }}}$} \\
\hline & \multicolumn{4}{|c|}{$\begin{array}{l}\text { Panel A: active and passive changes } \\
\text { in capital }\end{array}$} & \multicolumn{4}{|c|}{$\begin{array}{l}\text { Panel B: active change in } \\
\text { capital }\end{array}$} \\
\hline & \multicolumn{2}{|c|}{ (1) } & \multicolumn{2}{|c|}{ (2) } & \multicolumn{2}{|c|}{ (1) } & \multicolumn{2}{|c|}{ (2) } \\
\hline & Eq.5 & Eq.6 & Eq.5 & Eq.6 & Eq.5 & Eq.6 & Eq.5 & Eq.6 \\
\hline \multirow[t]{2}{*}{$\mathrm{TDE}_{\mathrm{it}}(\lambda)$} & $0.44^{* * * *}$ & $0.43^{* * *}$ & $0.40^{* * * *}$ & $0.42^{* * *}$ & $0.42^{* * n+4}$ & $0.39^{* * *}$ & $0.39^{* * * *}$ & $0.37^{* * * *}$ \\
\hline & $(0.00)$ & $(0.00)$ & $(0.00)$ & $(0.00)$ & $(0.00)$ & $(0.00)$ & $(0.00)$ & $(0.00)$ \\
\hline \multirow{2}{*}{$\mathrm{TDE}_{\mathrm{it}} \times \mathrm{BELOW}_{\mathrm{it}-1}(\theta)$} & 0.01 & 0.03 & 0.01 & 0.02 & 0.01 & 0.02 & 0.05 & 0.03 \\
\hline & $(0.30)$ & $(0.53)$ & $(0.12)$ & $(0.29)$ & $(0.40)$ & $(0.29)$ & $(0.57)$ & $(0.35)$ \\
\hline \multirow[t]{2}{*}{$\mathrm{TDE}_{\mathrm{it}} \times \mathrm{W}_{\mathrm{i}} \quad\left(\lambda^{\prime}\right)$} & 0.01 & 0.01 & 0.02 & 0.02 & 0.06 & 0.04 & -0.02 & 0.01 \\
\hline & $(0.34)$ & $(0.38)$ & $(0.19)$ & $(0.52)$ & $(0.60)$ & $(0.48)$ & $(0.73)$ & $(0.45)$ \\
\hline \multirow{2}{*}{$\mathrm{TDE}_{\mathrm{it}} \times \mathrm{BELOW}_{\mathrm{it}-1} \times \mathrm{W}_{\mathrm{i}}\left(\theta^{\prime}\right)$} & -0.21 & $-0.17^{*}$ & $-0.17^{* *}$ & $-0.17^{*}$ & $-0.42^{* * *}$ & $-0.38^{* * *}$ & $-0.38^{* *}$ & $-0.35^{* * *+}$ \\
\hline & $(0.15)$ & $(0.09)$ & $(0.04)$ & $(0.06)$ & $(0.01)$ & $(0.00)$ & $(0.03)$ & $(0.00)$ \\
\hline \multirow[t]{2}{*}{ INTERCEPT } & $0.26^{* * * *}$ & 0.14 & $0.43^{* * * *}$ & 0.183 & 0.07 & 0.12 & 0.10 & $-0.33^{* *+*}$ \\
\hline & $(0.00)$ & $(0.34)$ & $(0.00)$ & $(0.134)$ & $(0.27)$ & $(0.17)$ & $(0.24)$ & $(0.00)$ \\
\hline Number of observations & 1488 & 1485 & 1472 & 1477 & 1485 & 1477 & 1469 & 1472 \\
\hline$\lambda+\theta$ & 0.45 & 0.46 & 0.41 & 0.44 & 0.43 & 0.41 & 0.44 & 0.40 \\
\hline Risk level to reject $\lambda+\theta=0$ & 0.00 & 0.00 & 0.00 & 0.00 & 0.00 & 0.00 & 0.00 & 0.00 \\
\hline$\lambda+\lambda^{\prime}$ & 0.45 & 0.44 & 0.42 & 0.44 & 0.48 & 0.43 & 0.37 & 0.38 \\
\hline Risk level to reject $\lambda+\lambda^{\prime}=0$ & 0.00 & 0.00 & 0.00 & 0.00 & 0.00 & 0.00 & 0.00 & 0.00 \\
\hline$\lambda+\theta+\lambda^{\prime}+\theta^{\prime}$ & 0.25 & 0.30 & 0.26 & 0.29 & 0.07 & 0.07 & 0.04 & 0.06 \\
\hline Risk level to reject $\lambda+\theta+\lambda^{\prime}+\theta^{\prime}=0$ & 0.00 & 0.00 & 0.00 & 0.00 & 0.50 & 0.16 & 0.60 & 0.23 \\
\hline
\end{tabular}

Table F.4 reports the estimation results for equation (4) using fixed effect estimator on the subsample of European Commercial banks above the regulatory capital minimum over the $2002-2010$ period. $A_{D E} E_{i t}=\frac{K_{i t}}{A_{i t}}-\frac{\widetilde{K}_{i t-1}}{A_{i t}}$, is the actual deviation. $\mathrm{TDE}_{\mathrm{it}}=\left(\frac{\mathrm{K}_{\mathrm{it}}}{\mathrm{A}_{\mathrm{it}}}\right)^{*}-\frac{\widetilde{\mathrm{K}}_{\mathrm{it}-1}}{\mathrm{~A}_{\mathrm{it}}}$, is the target deviation. $\widetilde{\mathrm{K}}_{\mathrm{it}-1}$ is defined as the lagged value of Tier 1 regulatory capital in panel $\mathrm{A}$, and as is the sum of the lagged value of Tier 1 regulatory capital and the current net income minus the current dividend payment in panel B. $\left(\frac{\mathrm{K}_{\mathrm{it}}}{\mathrm{A}_{\mathrm{it}}}\right)^{*}$ is the target capital ratio defined respectively as the non-weighted Tier 1 capital ratio (T1_TA) and risk-based Tier 1 capital ratio (T1_RWA) in columns (1) and (2). In columns Eq.5 and Eq.6, we respectively estimate the target capital ratio using equations 5 (GMM) and 6 (Random Effect Estimator). BELOW $\mathrm{W}_{\mathrm{it}-1}$ is a dummy variable equal to one if the bank capital ratio is below the target at $t-1$, and zero otherwise. $\mathrm{W}_{\mathrm{i}}$ is a dummy variable equal to one if there is a gap between voting and cash-flow rights of the ultimate shareholder, and zero otherwise. P-values are shown in parentheses. ${ }^{*} \mathrm{p}<0.1,{ }^{* *} \mathrm{p}<0.05,{ }^{* * *} \mathrm{p}<0.01$. 


\section{Table F.5}

Capital adjustment speed and ownership structure over the 2002-2010 period for the whole sample using a target capital ratio that controls for ownership structure

\begin{tabular}{|c|c|c|c|c|c|c|c|c|}
\hline \multirow[t]{4}{*}{ Dependent variable } & \multicolumn{8}{|c|}{$\mathbf{A D E}_{\mathrm{it}}$} \\
\hline & \multicolumn{4}{|c|}{$\begin{array}{l}\text { Panel A: active and passive changes } \\
\text { in capital }\end{array}$} & \multicolumn{4}{|c|}{$\begin{array}{l}\text { Panel B: active change in } \\
\text { capital }\end{array}$} \\
\hline & \multicolumn{2}{|c|}{ (1) } & \multicolumn{2}{|c|}{ (2) } & \multicolumn{2}{|c|}{ (1) } & \multicolumn{2}{|c|}{ (2) } \\
\hline & Eq.5 & Eq.6 & $\mathrm{Eq.5}$ & Eq.6 & Eq.5 & Eq.6 & $\mathrm{Eq} .5$ & Eq.6 \\
\hline \multirow[t]{2}{*}{$\mathrm{TDE}_{i t}(\lambda)$} & $0.45^{* * *}$ & $0.46^{* * *}$ & $0.47^{* * *}$ & $0.45^{* * *}$ & $0.43^{* * *}$ & $0.40^{* * *}$ & $0.39^{* * *}$ & $0.42^{* * *}$ \\
\hline & $(0.00)$ & $(0.00)$ & $(0.00)$ & $(0.00)$ & $(0.00)$ & $(0.00)$ & $(0.00)$ & $(0.00)$ \\
\hline \multirow[t]{2}{*}{$\mathrm{TDE}_{\mathrm{it}} \times \mathrm{BELOW}_{\mathrm{it}-1}(\theta)$} & 0.01 & 0.03 & -0.01 & 0.02 & 0.01 & -0.01 & 0.03 & -0.01 \\
\hline & $(0.15)$ & $(0.27)$ & $(0.39)$ & $(0.36)$ & $(0.26)$ & $(0.12)$ & $(0.19)$ & $(0.43)$ \\
\hline \multirow[t]{2}{*}{$\mathrm{TDE}_{\mathrm{it}} \times \mathrm{W}_{\mathrm{i}} \quad\left(\lambda^{\prime}\right)$} & 0.02 & 0.04 & 0.03 & 0.04 & -0.01 & 0.01 & 0.03 & -0.02 \\
\hline & $(0.17)$ & $(0.37)$ & $(0.10)$ & $(0.32)$ & $(0.22)$ & $(0.32)$ & $(0.20)$ & $(0.21)$ \\
\hline \multirow[t]{2}{*}{$\mathrm{TDE}_{\mathrm{it}} \times \mathrm{BELOW}_{\mathrm{it}-1} \times \mathrm{W}_{\mathrm{i}}\left(\theta^{\prime}\right)$} & -0.24 & $-0.25^{* *}$ & -0.22 & $-0.23^{*}$ & $-0.35^{* *}$ & $-0.34^{* * *}$ & $-0.35^{*}$ & $-0.30^{* * *}$ \\
\hline & $(0.10)$ & $(0.06)$ & $(0.26)$ & $(0.09)$ & $(0.04)$ & $(0.00)$ & $(0.06)$ & $(0.00)$ \\
\hline \multirow[t]{2}{*}{ INTERCEPT } & $0.21^{* * *}$ & $0.32^{* *}$ & $0.23^{*}$ & 0.25 & 0.20 & 0.12 & 0.11 & $0.12^{* * *}$ \\
\hline & $(0.00)$ & $(0.04)$ & $(0.09)$ & $(0.20)$ & $(0.26)$ & $(0.31)$ & $(0.29)$ & $(0.00)$ \\
\hline Number of observations & 1492 & 1492 & 1476 & 1485 & 1489 & 1485 & 1473 & 1479 \\
\hline$\lambda+\theta$ & 0.46 & 0.49 & 0.46 & 0.47 & 0.44 & 0.39 & 0.42 & 0.41 \\
\hline Risk level to reject $\lambda+\theta=0$ & 0.00 & 0.00 & 0.00 & 0.00 & 0.00 & 0.00 & 0.00 & 0.00 \\
\hline$\lambda+\lambda^{\prime}$ & 0.47 & 0.50 & 0.50 & 0.49 & 0.42 & 0.41 & 0.42 & 0.40 \\
\hline Risk level to reject $\lambda+\lambda^{\prime}=0$ & 0.00 & 0.00 & 0.00 & 0.00 & 0.00 & 0.00 & 0.00 & 0.00 \\
\hline$\lambda+\theta+\lambda^{\prime}+\theta^{\prime}$ & 0.31 & 0.27 & 0.27 & 0.28 & 0.08 & 0.06 & 0.10 & 0.09 \\
\hline Risk level to reject $\lambda+\theta+\lambda^{\prime}+\theta^{\prime}=0$ & 0.00 & 0.00 & 0.00 & 0.00 & 0.42 & 0.46 & 0.18 & 0.39 \\
\hline
\end{tabular}

Table F.6 reports the estimation results for equation (4) using fixed effect estimator for the whole sample of European Commercial over the period 2002-2010 using a target capital ratio that controls for ownership structure. $A D E_{i t}=\frac{K_{i t}}{A_{i t}}-\frac{\widetilde{K}_{i t-1}}{A_{i t}}$, is the actual deviation. $\mathrm{TDE}_{\mathrm{it}}=\left(\frac{\mathrm{K}_{\mathrm{it}}}{\mathrm{A}_{\mathrm{it}}}\right)^{*}-\frac{\widetilde{\mathrm{K}}_{\mathrm{it}-1}}{\mathrm{~A}_{\mathrm{it}}}$, is the target deviation. $\widetilde{\mathrm{K}}_{\mathrm{it}-1}$ is defined as the lagged value of Tier 1 regulatory capital in panel A, and as is the sum of the lagged value of Tier 1 regulatory capital and the current net income minus the current dividend payment in panel B. $\left(\frac{\mathrm{K}_{\mathrm{it}}}{\mathrm{A}_{\mathrm{it}}}\right)^{*}$ is the target capital ratio defined respectively as the non-weighted Tier 1 capital ratio (T1_TA) and risk-based Tier 1 capital ratio (T1_RWA) in columns (1) and (2). In columns Eq.5 and Eq.6, we respectively estimate the target capital ratio using equations 5 (GMM) and 6 (Random Effect Estimator). BELOW $\mathrm{Bt}_{\mathrm{it}-1}$ is a dummy variable equal to one if the bank capital ratio is below the target at $t-1$, and zero otherwise. $W_{i}$ is a dummy variable equal to one if there is a gap between voting and cash-flow rights of the ultimate shareholder, and zero otherwise. Pvalues are shown in parentheses. $\mathrm{p}<0.1,{ }^{* *} \mathrm{p}<0.05,{ }^{* * *} \mathrm{p}<0.01$. 


\section{Table F.6}

Capital adjustment speed and ownership structure over the 2002-2010 period for the whole sample using a $20 \%$ control threshold

\begin{tabular}{|c|c|c|c|c|c|c|c|c|}
\hline \multirow[t]{4}{*}{ Dependent variable } & \multicolumn{8}{|c|}{$\mathrm{ADE}_{\mathrm{it}}$} \\
\hline & \multicolumn{4}{|c|}{$\begin{array}{l}\text { Panel A: active and passive changes } \\
\text { in capital }\end{array}$} & \multicolumn{4}{|c|}{$\begin{array}{l}\text { Panel B: active change in } \\
\text { capital }\end{array}$} \\
\hline & \multicolumn{2}{|c|}{ (1) } & \multicolumn{2}{|c|}{ (2) } & \multicolumn{2}{|c|}{ (1) } & \multicolumn{2}{|c|}{ (2) } \\
\hline & Eq.5 & Eq.6 & $\mathrm{Eq} .5$ & Eq.6 & Eq.5 & Eq.6 & Eq.5 & Eq.6 \\
\hline \multirow[t]{2}{*}{$\mathrm{TDE}_{i \mathrm{it}}(\lambda)$} & $0.46^{* * *}$ & $0.46^{* * *}$ & $0.44^{* * *}$ & $0.43^{* * *}$ & $0.41^{* * *}$ & $0.37^{* * *}$ & $0.39^{* * *}$ & $0.40^{* * *}$ \\
\hline & $(0.00)$ & $(0.00)$ & $(0.00)$ & $(0.00)$ & $(0.00)$ & $(0.00)$ & $(0.00)$ & $(0.00)$ \\
\hline \multirow[t]{2}{*}{$\mathrm{TDE}_{\mathrm{it}} \times \mathrm{BELOW}_{\mathrm{it}-1}(\theta)$} & 0.05 & 0.02 & 0.08 & 0.06 & -0.01 & 0.03 & 0.02 & 0.01 \\
\hline & $(0.55)$ & $(0.15)$ & $(0.25)$ & $(0.63)$ & $(0.39)$ & $(0.31)$ & $(0.21)$ & $(0.18)$ \\
\hline \multirow[t]{2}{*}{$\mathrm{TDE}_{\mathrm{it}} \times \mathrm{W}_{\mathrm{i}} \quad\left(\lambda^{\prime}\right)$} & 0.06 & 0.03 & 0.06 & 0.06 & -0.03 & 0.02 & -0.01 & 0.01 \\
\hline & $(0.68)$ & $(0.72)$ & $(0.51)$ & $(0.26)$ & $(0.31)$ & $(0.20)$ & $(0.12)$ & $(0.12)$ \\
\hline \multirow[t]{2}{*}{$\mathrm{TDE}_{\mathrm{it}} \times \mathrm{BELOW}_{\mathrm{it}-1} \times \mathrm{W}_{\mathrm{i}}\left(\theta^{\prime}\right)$} & $-0.26^{*}$ & -0.24 & -0.29 & $-0.25^{* *}$ & $-0.32^{* *}$ & $-0.38^{* * *}$ & $-0.32^{* *}$ & $-0.35^{* * *}$ \\
\hline & $(0.08)$ & $(0.38)$ & $(0.67)$ & $(0.04)$ & $(0.03)$ & $(0.00)$ & $(0.02)$ & $(0.47)$ \\
\hline \multirow[t]{2}{*}{ INTERCEPT } & $0.33^{* * *}$ & $0.29^{* * *}$ & $0.31^{* * *}$ & 0.20 & 0.07 & -0.06 & -0.01 & $-0.26^{* *}$ \\
\hline & $(0.00)$ & $(0.00)$ & $(0.00)$ & $(0.11)$ & $(0.18)$ & $(0.38)$ & $(0.87)$ & $(0.02)$ \\
\hline Number of observations & 1522 & 1524 & 1507 & 1513 & 1518 & 1514 & 1503 & 1506 \\
\hline$\lambda+\theta$ & 0.51 & 0.48 & 0.52 & 0.49 & 0.40 & 0.40 & 0.41 & 0.41 \\
\hline Risk level to reject $\lambda+\theta=0$ & 0.00 & 0.00 & 0.00 & 0.00 & 0.00 & 0.00 & 0.00 & 0.00 \\
\hline$\lambda+\lambda^{\prime}$ & 0.52 & 0.49 & 0.50 & 0.49 & 0.38 & 0.39 & 0.38 & 0.41 \\
\hline Risk level to reject $\lambda+\lambda^{\prime}=0$ & 0.00 & 0.00 & 0.00 & 0.00 & 0.00 & 0.00 & 0.00 & 0.00 \\
\hline$\lambda+\theta+\lambda^{\prime}+\theta^{\prime}$ & 0.31 & 0.27 & 0.29 & 0.30 & 0.05 & 0.04 & 0.08 & 0.07 \\
\hline Risk level to reject $\lambda+\theta+\lambda^{\prime}+\theta^{\prime}=0$ & 0.00 & 0.00 & 0.00 & 0.00 & 0.58 & 0.56 & 0.67 & 0.60 \\
\hline
\end{tabular}

Table F.5 reports the estimation results for equation (4) using fixed effect estimator on the whole sample of European Commercial using a $20 \%$ control threshold over the 2002-2010 period. $A D E_{i t}=\frac{K_{i t}}{A_{i t}}-\frac{\widetilde{K}_{i t-1}}{A_{i t}}$, is the actual deviation. $\mathrm{TDE}_{\mathrm{it}}=\left(\frac{\mathrm{K}_{\mathrm{it}}}{\mathrm{A}_{\mathrm{it}}}\right)^{*}-\frac{\widetilde{\mathrm{K}}_{\mathrm{it}-1}}{\mathrm{~A}_{\mathrm{it}}}$, is the target deviation. $\widetilde{\mathrm{K}}_{\mathrm{it}-1}$ is defined as the lagged value of Tier 1 regulatory capital in panel A, and as is the sum of the lagged value of Tier 1 regulatory capital and the current net income minus the current dividend payment in panel B. $\left(\frac{\mathrm{K}_{\mathrm{it}}}{\mathrm{A}_{\mathrm{it}}}\right)^{*}$ is the target capital ratio defined respectively as the non-weighted Tier 1 capital ratio (T1_TA) and risk-based Tier 1 capital ratio (T1_RWA) in columns (1) and (2). In columns Eq.5 and Eq.6, we respectively estimate the target capital ratio using equations 5 (GMM) and 6 (Random Effect Estimator). BELOW it-1 $_{1}$ is a dummy variable equal to one if the bank capital ratio is below the target at $\mathrm{t}-1$, and zero otherwise. $\mathrm{W}_{\mathrm{i}}$ is a dummy variable equal to one if there is a gap between voting and cash-flow rights of the ultimate shareholder, and zero otherwise. P-values are shown in parentheses. ${ }^{*} \mathrm{p}<0.1,{ }^{* *} \mathrm{p}<0.05,{ }^{* * *} \mathrm{p}<0.01$. 